IZA DP No. 10351

Rainfall Risk and Fertility:

Evidence from Farm Settlements during the American Demographic Transition

Michael Grimm

November 2016 


\title{
Rainfall Risk and Fertility: Evidence from Farm Settlements during the American Demographic Transition
}

\author{
Michael Grimm \\ University of Passau, \\ Erasmus University Rotterdam and IZA
}
Discussion Paper No. 10351
November 2016

\author{
IZA \\ P.O. Box 7240 \\ 53072 Bonn \\ Germany \\ Phone: +49-228-3894-0 \\ Fax: +49-228-3894-180 \\ E-mail: iza@iza.org
}

Any opinions expressed here are those of the author(s) and not those of IZA. Research published in this series may include views on policy, but the institute itself takes no institutional policy positions. The IZA research network is committed to the IZA Guiding Principles of Research Integrity.

The Institute for the Study of Labor (IZA) in Bonn is a local and virtual international research center and a place of communication between science, politics and business. IZA is an independent nonprofit organization supported by Deutsche Post Foundation. The center is associated with the University of Bonn and offers a stimulating research environment through its international network, workshops and conferences, data service, project support, research visits and doctoral program. IZA engages in (i) original and internationally competitive research in all fields of labor economics, (ii) development of policy concepts, and (iii) dissemination of research results and concepts to the interested public.

IZA Discussion Papers often represent preliminary work and are circulated to encourage discussion. Citation of such a paper should account for its provisional character. A revised version may be available directly from the author. 


\section{ABSTRACT \\ Rainfall Risk and Fertility: Evidence from Farm Settlements during the American Demographic Transition*}

Fertility is a main driver and outcome of long-term growth. Yet, fertility may not only interact with the level of income but also with its volatility. In pre-modern economies where formal social security was largely absent, fertility decisions may also have been made in view of insuring income shocks which were hard to predict such as an income shock due to crop disease, a shortage in rainfall, a case of serious illness or a job loss. In this paper, I focus on the demographic transition in the United States covering the period 1870 to 1930 and explore whether variation in fertility among American settlers can be explained by variations in exposure to rainfall risks. Identification relies on fertility differences between farm and nonfarm households within counties and over time. The results suggest that increased rainfall risk does indeed increase fertility among farming households but not among households with other occupations that are less dependent on rainfall. The channel is robust to other relevant forces such as returns to education and children's survival. The analysis also shows that this effect is reduced if risk management devices such as irrigation systems, formal financial institutions or machinery emerge. The findings contribute to the understanding of the demographic transition in the US and in risk-prone areas more generally.

JEL Classification: J13, N31, N32, O12, Q12

Keywords: demographic transition, rainfall risk, income shocks, insurance, historical data

Corresponding author:

Michael Grimm

Chair of Development Economics

University of Passau

Innstraße 29

94032 Passau

Germany

E-mail: michael.grimm@uni-passau.de

\footnotetext{
* I thank Stefan Bauernschuster, Ram Fishman, Stephan Klasen, Uwe Sunde and participants at research seminars at the University of Göttingen, the Vienna Institute of Demography, the University of Regensburg, the University of Bordeaux and at the CSAE conference in Oxford for valuable comments. I also thank Levke Jessen-Thiesen and Hendrik Kampert for excellent research assistance.
} 


\section{Introduction}

According to unified growth theory fertility is a main driver and outcome of long-term growth (Galor and Weil, 2000; Galor and Moav, 2002; Galor, 2012). Yet, fertility may not only interact with the level of income but also with its volatility. In pre-modern economies where formal social security was largely absent, fertility decisions may, for example, have been made to provide old-age security (Neher, 1971; Willis, 1980; Caldwell, 1982; Ehrlich and Lui, 1991). Although the argument sounds compelling, the empirical evidence in support of this argument is mixed (see e.g. Nugent, 1985; Jensen, 1990; Rendall and Bahchieva, 1998). In particular Galor (2012) shows that at least for the demographic transition in Western countries the decline in the importance of old-age support is unlikely to be a major force behind the significant reduction in fertility. Surprisingly, only very few studies have examined whether fertility decisions were also made in view of insuring income shocks that occur much earlier in life and which are hard to predict such as an income shock due to crop disease, a shortage in rainfall, a case of serious illness or a job loss. This fertility motive was first discussed by Cain (Cain, 1981, 1983, 1986) and, more generally, by Pörtner (2001). The idea is that children can be used to smooth consumption over time by providing additional labor in the event of a shock. Children can also free up the time of older household members by taking on household chores such as cooking, cleaning or taking care of their younger siblings. De Vany and Sanchez (1979), Cain (1990) and Das Gupta (1995) provide descriptive evidence in support of this motive for the context of developing countries. More robust evidence comes from Pörtner (2011) who uses the geographical variation in hurricane risk across municipalities in Guatemala to examine the effect of risk-exposure on fertility.

In this paper I focus on the demographic transition in the United States. I empirically analyze whether variation in fertility among American settlers in the second half of the nineteenth and first half of the twentieth century can be explained by variations in exposure to rainfall risks and whether the emergence of risk-mitigating devices such as irrigation systems and financial 
services boosted the demographic transition by reducing the need to have many children. Though the mechanism is unlikely to be a major force in the demographic transition, it could be an important element to understand differences in the pace of the fertility decline in farm and non-farm households and across different climate zones. American census data provides information about fertility and the 'PRISM Climate Group' information about rainfall, thus allowing the exploration of this link. The identification relies on fertility differences between farm and non-farm households within counties and over time. I consider both longer term rainfall variability and short term changes in rainfall variability.

The results suggest that increased rainfall risk does indeed increase fertility among farming households but not among households with other occupations that are less dependent on rainfall. The analysis also shows, however, that this effect disappears, or is at least strongly reduced, if risk-mitigating devices emerge. The results are robust to the inclusion of competing channels such as school enrolment and children's survival. The findings in this paper also have potentially important implications for Sub-Saharan Africa, in particular for those areas where income risks are a major threat to households and where fertility is still high and only slowly declining or not declining at all.

This study adds to the vast body of literature that has analyzed the determinants of the demographic transition in the US. ${ }^{1}$ It is closely related to two other recent papers that looked at households' behavior and risk during the nineteenth century in America. Ager and Ciccone (2014) show that religious membership strongly varied with risk exposure, suggesting that Americans at that time also tried to cope with risks through informal insurance schemes that were set up within religious communities. Basso et al. (2014) show that fertility decisions by Americans (using data from eight Northeastern states) varied according to the degree of

\footnotetext{
${ }^{1}$ See e.g. Yasuba (1962), Forster and Tucker (1972), Easterlin (1976, 2000), Vinovskis (1976), Haines (2000), Greenwood and Seshadri (2002), Hacker (2003), Haines and Hacker (2006), Johnson and Rathge (2006), Jones and Tertilt (2006), Bleakley and Lange (2009), Aaronson et al. (2014), Hansen et al. (2014), Lahey (2014) and Ager et al. (2015).
} 
financial development, i.e. in those areas where the financial system was already more advanced, fertility rates were much lower. The authors interpret their findings as evidence in support of the old age insurance motive.

Examining the role of the insurance motive for the American demographic transition is particularly interesting as at the time most rural households generated their income from agriculture, particularly households in the Central region of the country, and hence had to cope with the many risks and uncertainties which significantly shaped their lives. The most well-known crises people had to go through were the widespread death of cattle in 1886, the influenza pandemic in 1918, the agricultural recession in 1920 and the immense drought in the 1930s, also known as the dust bowl (Thomson and Whelpton, 1933). Fertility was generally higher in new settlement regions than in old settlement regions even when only considering rural areas. Easterlin (2000) argues that this can be explained by land abundance and high returns in agricultural production in newer settlement regions which in turn allowed for the generous bequeathing to many children. In contrast, in older areas, land started to become scarce and farmers became increasingly concerned about providing for their children and hence reduced fertility. Similar arguments were made by Yasuba (1962) and Forster and Tucker (1972).

The remainder of the paper is organized as follows. Section 2 presents the theoretical framework underlying this paper. Section 3 further describes the context of this study. Section 4 presents the data used and outlines the empirical identification strategy. Section 5 presents the results and various robustness checks. Section 6 concludes.

\section{Context and some theoretical considerations}

This study focuses on the period between the civil war and the great depression. Whereas the Northeast, the Mid-Atlantic, the Southeast and the West were already quite densely settled, the South, North and Midwest were still subject to substantial population movements 
(Gallaway et al., 1974). The fertility transition was relatively advanced in New England, but in the rest of the country the total, particularly in the South, fertility rate was well above four children per woman (Jones and Tertilt, 2006). In the second part of the nineteenth century, the country was, with the exception of the Northeast, still very rural, with more than half of the population working in agriculture, typically on small family-owned farms relying only on horse and manpower (Perelman, 1973; Dimitri et al., 2005; Dempster and Isaacs, 2014). This started to change rapidly at the beginning of the twentieth century as innovations such as the tractor, fertilization and other sophisticated inputs emerged which increased productivity substantially, allowing for larger farms and freeing up labor for the simultaneously ongoing industrialization (Dimitri et al., 2005). According to Perelman (1973), the horsepower provided by tractors rose from 5 million hp in 1920 to 93 million hp in 1950. Since 1900, new technologies and the development of rural infrastructure brought farming households closer to national markets for labor and capital, as well as goods and services (Dimitri et al., 2005). This positive dynamic was abruptly stopped with the start of the great depression during which prices for food and cash crops collapsed. This, in conjunction with the financial sector crisis, led to the closure of many farms.

In the second half of the nineteenth century it was normal for children to help on farms: children also increasingly worked in industry in places where such opportunities existed. Many children combined work with schooling (Walters and O’Connell, 1988). Compared to households in the Northeast region, child work was somewhat more common in the Midwest and substantially more common in the Southern states (Horan and Hargis, 1991). School enrolment in the Southern states was substantially lower. Recall that fertility levels were also substantially higher in that region. Laws regulating child labor existed in some states, but where typically only strictly enforced after the great depression in order to avoid children taking the jobs of adults (US Department of Labor, 1968). 
In the event of shocks, children could free up time of other household members by taking on household chores, including taking care of younger siblings, so that these other household members could increase their labor market participation (Walters and O’Connell, 1988). Children could also help on the family farm or work on other farms or in industry (Horan and Hargis, 1991). So there is no doubt that children could potentially help to smooth income if needed. There is also plenty of evidence from developing countries today that children's labor supply is a common ex-post coping strategy (see e.g., Edmonds, 2006; Duryea et al., 2007; Landman and Frölich 2015). Children obviously also generated costs, but as long as they could reduce the variance in income, they may have increased households' welfare. Children could of course die, yet this probably made children no riskier than many other forms of insurance. Own children were probably also more trusted than support from outside the family (see also Pörtner, 2001).

\section{Data}

I use four different data sources: population census data, agricultural census data, data from the survey on banks and bank deposits and rainfall data. I present each source in turn.

Historical population census data is available from the Integrated Public Use Microdata Series (IPUMS). I use the data from the years 1870, 1880, 1900, 1910, 1920 and 1930. IPUMS provides $1 \%$ samples in each year. Additionally, for 1880 IPUMS provides a $10 \%$ sample and for 1900 and 1930 a 5\% sample each. Hence for 1880, 1900 and 1930 I use the larger samples. ${ }^{2}$ The 1890 census records were destroyed by fire and flooding and are not available for analysis. From the census data I draw individual-level information about women's fertility, their age, their education, their spouse's education and their location (urban or rural and their county). The number of children ever born is unfortunately only available for 1900 and 1940 onwards. For earlier years there is just the total number of children living in the

\footnotetext{
${ }^{2}$ IPUMS recently also released preliminary versions of full count data for the years 1880, 1920 and 1930.
} 
household or the number below the age of five living in the household. I follow Basso et al. (2014) and compute for each 15 to 39-year-old woman the number of children below the age of five living in the household. Using child-woman ratios as a measure of fertility is quite common in the historical literature (see e.g. also, Becker et al., 2013). This variable will follow a similar trend as that for the number of children ever born if, in the course of the demographic transition, women start childbearing later and increase birth intervals proportionally. If, in contrast, women maintain their birth intervals but just stop earlier in order to end up with fewer children, the number of children below the age of five living in the household will somewhat underestimate the real fertility decline. To check whether this might be a concern I have computed the decline between 1900 and 1940 for both variables and compared their trends. This is illustrated in Figure S.1 in the online appendix. It can be seen that indeed the number of children below five seems to decline a little bit slower than the number of children ever born, but the difference is rather small. It is also less of a concern as I am more interested, as I will show below, in fertility differences across space rather than in absolute fertility levels. Other authors have constructed retrospectively fertility data by using the number of children ever born reported in the 1940 census. Yet, in my case this is not a preferable option as women may have changed the county between the birth of their children and 1940. In addition selective mortality could bias the results.

The Census of Agriculture provides data for the same years as the population census, although the set of questions was modified over time so that there is only a limited set of consistent variables for all years. I use the average value of farmland and buildings, the average farmland area per farm and the average value of implements and machinery per farm. For the years 1900 and 1910 there is also information about the existence of irrigation systems. The data is provided by the National Historical Geographic Information System (NHGIS). 
For the analysis I use only the information about white women. I exclude the states of Alaska and Hawaii and the population living in military camps. I also limit the analysis to women living in rural areas. ${ }^{3}$ I remove those observations where information on key variables is missing. ${ }^{4}$ Table 1 shows the composition of the total sample used for the estimation. There are $1,460,754$ observations in the relevant age group. It can be seen that the number of covered counties increases over time as, at the beginning of the observation window, many counties were not yet settled. The sample comprises on average 5,962 rural white women aged 15 to 39 per county. Figure 1 shows the evolution of the used fertility measure by region over time (see Figure A.1 for the exact division). It can be seen that there are significant differences in the advancement of the demographic transition and in the speed of change. Figure 2 shows a set of maps tracking the fertility decline in rural areas across counties over time. White areas indicate areas where no census was conducted since the population density was too low.

[Table 1 and Figures 1 and 2 about here]

Table 2 describes the sample over time by showing the mean of each variable in each census year. The used fertility measure declines by almost $18 \%$ over the entire observation window. Literacy also increases over time. At the end of the observation window, female literacy exceeds literacy levels of household heads; this is largely due to the fact that our female sample is younger than the corresponding (mostly male) household heads. The share of farming households at first increases and then, at the beginning of the twentieth century, declines. The size of farms, the value of farmland and farm buildings and the value of machinery and implements also continuously rises. The increase in the value of machinery

\footnotetext{
${ }^{3}$ The term 'rural' generally denotes places with less than 2,500 inhabitants. There is a slight variation over time with respect to the coding within the New England states.

${ }^{4}$ The only information that is not available for all women is the information that comes from the Census of Agriculture. The fact that a few counties were not covered removes $1.8 \%$ from the sample.
} 
and implements is particularly pronounced after 1900, documenting the increasing use, in particular, of capital, tractors and reapers in agriculture.

[Table 2 about here]

In Table 3 I show the same descriptive statistics for the years 1880 and 1930 in four regions: New England, and the Atlantic, Central and Mountains and Pacific regions (see Figure A.1 for the exact division). These regions differ regarding their level of fertility and female education. At that time New England even experienced a slight increase in fertility which has also been documented in previous studies (see e.g. Jones and Tertilt, 2006). In terms of capital invested in agriculture and farm size, the Central part of the US and the Mountains/Pacific region was able to catch up with New England and even increase beyond it by 1930 .

[Table 3 about here]

For the years 1920 and 1930, data from the Survey of banks and bank deposits allows to explore the impact of financial market development on fertility, in particular in interaction with rainfall risk. Descriptive statistics are included in Table 2.

Finally, rainfall data comes from the PRISM data set. For the US it provides monthly rainfall data for the period 1895 to 1980 for 4 x 4 km grid points. ${ }^{5}$ Using the minimal Euclidian distance, I attributed each rainfall station to a specific county and computed for each county and each month the average rainfall. From this I computed the average rainfall during the growing season (assumed to last from March to November) for each county and year. Based on these means, I computed the variance in rainfall for each county. For both average rainfall and the variance in rainfall I use log rainfall in order to capture relative rather than absolute deviations from the mean. As an alternative measure of rainfall risk, I also computed the

\footnotetext{
${ }^{5}$ The dataset uses whatever station networks and data sources are available for the relevant period. The rainfall time series were modelled using climatologically-aided interpolation (CAI), i.e. the Parameter-elevation Regressions on Independent Slopes Model (PRISM), which used the long-term average pattern as a first guess of the spatial pattern of climatic conditions for a given month or day. CAI is robust to wide variations in station data density, which is necessary when modeling long-term series. Data is based on monthly modelling.
} 
probability that a drought will occur, i.e. the probability that in a given year rainfall will be less than $75 \%$ of the long-term average rainfall (growing season) in that county. ${ }^{6}$

Figure 3 shows a set of maps documenting the distribution of rainfall, rainfall variation and droughts across the US. Rainfall levels are particularly high in the Northeast, along the Atlantic coast and in the Southeast more generally. The area to the left of the $100^{\circ}$ West meridian is very dry, yet rainfall is relatively high in Colorado, the Rockies and in the Northern part of the Pacific coast. Rain-fed agriculture was, without irrigation, barely possible in the West; livestock farming was the dominant activity. The following maps show that the rainfall variance and the probability of droughts varied substantially across the country. In the latter half of the nineteenth century the US experienced major droughts in 1856-1865, 18701877 and in 1890 and 1896 (Herweijer et al., 2004). In the first half of the twentieth century the dust bowl, i.e. a period of severe dust storms that caused enormous damage to farm land, farm yields and cattle, stands out. It started in the early 1930s and lasted several years (Worster, 1979). Since it started after 1930 it will not affect the analysis in this paper.

[Figure 3 about here]

\section{Empirical specification}

To identify the effect of rainfall risk on fertility I use the pooled sample of all census data covering the period from 1880 to 1930 . I regress fertility on the county-specific rainfall variance controlling for rainfall levels, individual, household and county characteristics in each census year and accounting for state-specific time effects in fertility. Since rainfall variability should, at least directly, only matter for farming households, I interact rainfall and rainfall variability with being in a farm household, which allows me to control for countyfixed effects. Hence identification relies on the differential effect of rainfall variability on

\footnotetext{
${ }^{6}$ I use alternatively the county-specific and the national long-term average.
} 
fertility between farm and non-farm households. ${ }^{7}$ Moreover, because the effect of rainfall variability may also change over time, for instance because agriculture becomes less dependent on rain as new technologies become available, I also interact rainfall and rainfall variability with time. Hence, the full model reads:

$$
\begin{array}{r}
\text { fert }_{i c s t}=\beta_{1}\left(\text { rain }_{c s} \times \text { farm }_{i c s t}\right)+\beta_{2}\left(\text { rain }_{c s} \times \text { farm }_{i c s t} \times T_{t}\right) \\
+\beta_{3}\left(\text { rainvar }_{c s} \times \text { farm }_{i c s t}\right)+\beta_{4}\left(\text { rainvar }_{c s} \times \text { farm }_{i c s t} \times T_{t}\right) \\
+X_{i c s t}^{\prime} \beta_{5}+C_{c s t}^{\prime} \beta_{6}+\vartheta_{c s}+\beta_{7}\left(\gamma_{s} \times T_{t}^{\prime}\right)+\varepsilon_{i c s t}(1)
\end{array}
$$

where rain stands for the average yearly rainfall level (in log) in the growing season, rainvar for the average yearly rainfall (in log) variance in the growing season, the matrix $X$ for a set of individual and household controls including age, education, education of the household head and whether the household is a farming household, the matrix $C$ stands time-varying for county-level controls such as the average value of farmland and buildings, machinery and implements and the average size of farmland per farm, $T$ stands for year effects (census years) and $\gamma_{s}$ for state effects. The parameter $\vartheta_{c}$ stands for county-fixed effects.

Since rainfall variability shows also some variation over time, I also use a specification, where rainfall variability is not calculated over the entire observation window covered by the PRISM data, but over ten year intervals around the census year, i.e. for the census of 1900 for the period 1895 to 1905 and for the census of 1910 for the period 1905 to 1915 . Obviously the virtue of this specification is that it creates within-county variation in rainfall-variability over time which can be used in addition for identification:

$$
\begin{array}{r}
\operatorname{fert}_{i c s t}=\beta_{1}\left(\operatorname{rain}_{c s t} \times \text { farm }_{i c s t}\right)+\beta_{2}\left(\text { rainvar }_{c s t} \times \text { farm }_{i c s t}\right)+ \\
+X^{\prime}{ }_{i c s t} \beta_{5}+C_{c s t}^{\prime} \beta_{6}+\vartheta_{c s}+\beta_{7}\left(\gamma_{s} \times T_{t}^{\prime}\right)+\varepsilon_{i c s t}(2)
\end{array}
$$

\footnotetext{
${ }^{7}$ Note that for 1870 and 1880 IPUMS coded a household as "farm household" if it contained at least one person with the occupation "farmer". In later years the coding was based on the enumerator's explicit identification of a farm (cultivated land, production and use of agricultural labor).
} 
Since the PRISM data only starts in 1895, this specification does not use the census data of 1870 and 1880:

To test for the effect of risk-mitigating technologies (I), I re-estimate Equation (1) as follows:

$$
\begin{array}{r}
\text { fert }_{i c s t}=\beta_{1}\left(\text { rain }_{c s} \times \text { farm }_{i c s t}\right)+\beta_{2}\left(\text { rain }_{c s} \times \text { farm }_{i c s t} \times I_{c s t}\right) \\
+\beta_{3}\left(\text { rainvar }_{c s} \times \text { farm }_{i c s t}\right)+\beta_{4}\left(\text { rainvar }_{c s} \times \text { farm }_{i c s t} \times I_{c s t}\right) \\
+X^{\prime}{ }_{i c s t} \beta_{5}+C_{c s t}^{\prime} \beta_{6}+\vartheta_{c s}+\beta_{7}\left(\gamma_{s} \times T_{t}^{\prime}\right)+\varepsilon_{i c s t}
\end{array}
$$

If the emergence of risk-mitigating technologies indeed reduces the need for more children to be able to cope with rainfall shocks, I should find $\beta_{4}<0$.

\section{Results}

\subsection{Main results}

A precondition for seeing an effect of rainfall variability on fertility that can be traced back to households' need for insurance, is that rainfall is a significant driver of agricultural production. Although there is little reason to doubt this link and despite the fact that in the literature it has been shown many times, I nevertheless verified that this link also holds true in my data. For this purpose, I regressed the county average value of production per farm in year $t$ on rainfall during the growing season in year $t$ controlling for average farm size, the average value of land per acre, the average value of machinery and implements per farm, period effects and county fixed effects. I find an elasticity of 0.34 , i.e. one percent more rainfall during the growing season increases the value of output by 0.34 percent. The results are shown in Table A.1 in the appendix. In what follows I therefore take for granted that rainfall variability leads to a variability in agricultural production and agricultural income. Table A.1 (cols. (4)-(6)) also shows that county-specific rainfall variability in itself, i.e. the extent to which rainfall typically varies from one year to another is in turn not a determinant of the value of production in year $t$ once rainfall in year $t$ is controlled for. Rainfall variability is measured here as the variance in rainfall over the period covering the five years prior and five 
years following the census year. Hence, if I find below an effect of rainfall variability on fertility, it is unlikely that this effect is driven by a simple income effect.

I now turn to the estimation of Equation (1). To show the sensitivity of the results with respect to different sets of controls and estimation methods I show several specifications. The results are shown in Table 4. Col. (1) does not yet account for county-fixed effects and state-time effects it just includes general time effects. Col. (2) controls for time effects but not yet statespecific time effects. Col. (3) excludes counties with less than 30 farm and 30 non-farm households just to ensure that the findings are not biased by those counties that have only few observations. 352 or $12 \%$ of all counties are dropped in this case (note that the average number of observations per county is 523). Col. (4) estimates year specific effects of rainfall variability on fertility, col. (5) allows in addition for state-specific time effects, col. (6) uses instead of rainfall variation the risk of drought measurement, col. (7) includes also urban areas in the analysis and col. (8) uses county means instead of individual data for estimation.

[Table 4 and Figure 4 about here]

The results in col. (1) show that the general effect of rainfall variability on fertility is negative, but the interaction effect with being in a farm household is positive and over-compensates the general negative effect. Hence, rainfall variability is associated with an increase in fertility in farm households but not in non-farm households. In the following specifications identification relies on that difference between farm and non-farm households within counties and hence all county-specific characteristics that do not vary over time and do not impact farm and nonfarm households differently are controlled for through the introduction of county-fixed effects.

In farm households the effect of rainfall variability on fertility is indeed across all specifications positive. Col. (2) suggests if rainfall variability is increased from a level that corresponds to the mean in the tenth percentile to the mean in the ninetieth percentile the number of children below the age of five in farm household increases on average by 0.07 or 
$12 \%$ of the mean relative to non-farm households. This is about half of the difference in fertility between literature and illiterate women. Such a shift in rainfall variability corresponds, for example, to a move from Chippewa, Michigan to Culberson, Texas. The estimated effect is almost exactly the same if counties with few observations are excluded from the sample (col. (3)). Cols. (4) and (5) reveal an interesting time pattern: The effect of rainfall variability on fertility observed for farm households is reduced as time progresses. Whereas the estimated effect is 0.932 in 1870 it decreases by about 70 percent to 0.295 in 1930 (cf. col. (5)). This means that if rainfall variability is increased, again, from a level that corresponds to the mean in the tenth percentile to the mean in the ninetieth percentile the number of children below the age of five in farm households relative to non-farm households increases in 1870 on average by 24 percent and in 1930 by only 8 percent, hence the fertility differential that is due to rainfall risk has almost disappeared by the end of the observation window. The time pattern is illustrated in more detail in Figure 4. During the period 1870 to 1930 the US experienced substantial social and economic change. In very arid areas, irrigation systems were built, formal safety nets and financial services became available and farms became more and more capital intensive. It also coincides with a massive expansion in the use of electricity. All this might have reduced the role of children in coping with rainfall risks. Whether this hypothesis is coherent with the empirical evidence will be explored in more detail below.

The results do also not change qualitatively if instead of rainfall risk the risk of drought is used (col. (6)). Including urban households into the sample does also not significantly change the results, the effect of rainfall variability just decreases somewhat. Finally, if the data is aggregated on the level of counties, separately for each year and farm and non-farm households, the results also hold. The effect of rainfall variability for farm households is still positive, only the period-specific effects are not anymore significant; but they are still negative and in terms of their absolute magnitude increasing over time. 
Before turning to estimates for sub-regions and further robustness checks, I will briefly comment on the effects associated with some of the control variables. The results show that the level of rainfall had only a small effect on fertility. If anything, rainfall seems rather to be associated with lower fertility, but less so as time progresses. But the effects are small and in many cases insignificant. As expected, literate women have lower fertility than illiterate women. Literacy of the household head, however, has the opposite effect, although this effect is small: fertility in households with a literate household head is about 0.04 children higher (or about 8\%) than in households with an illiterate head. Both effects taken together are coherent with a Beckerian demand-side model, but more tests would be required to see what exactly is the underlying mechanism; this is, however, beyond the scope of this paper. Fertility also decreases as the value of land and buildings per acre and farm size increases. The value of implements and machinery per farm alone has an insignificant or only very small positive effect. It is difficult to say what is driving the farm size effect. On the one hand larger farms may come with significant economies of scale and may allow households to rely more easily on hired labor, on the other hand, as Easterlin (2000) pointed out, more land makes it possible to bequest more to offspring which, according to Easterlin's argument, would allow parents to have more children. Overall, the regressions can explain about $16 \%$ of the variance in fertility. I also estimated the specifications shown in cols. (2) and (6) of Table 4 separately by region: I distinguish the New England states, the Atlantic states, the Central states and the Pacific/Mountain states (see Figure A.1 for the exact division). The results are shown in Table 5. For the New England states, rainfall variability does not have any effect on fertility. Given the advancement in industrialization in that part of the US, rainfall variability might, even in the late nineteenth century, not have induced a significant income risk, not even for agricultural households. In contrast, in counties located in the Atlantic and Central states, we notice a substantial effect on fertility associated with rainfall variability. In the Atlantic states the fertility differential between farm and non-farm households in the ninetieth percentile is 
by 0.48 children larger than in the tenth percentile, this corresponds to about $86 \%$ of the mean. In the central states the fertility differential between farm and non-farm households in the ninetieth percentile is still by 0.35 children larger than in the tenth percentile but in the central states this differential decreases as time progresses. In the Pacific and Mountain regions, where, due to the climate, agriculture was much less developed and important, no difference in fertility can be detected between farm and non-farm households.

[Table 5 about here]

To conclude, the results above suggest that at the end of the ninetieth century fertility was higher in those counties that were exposed to higher rainfall variability but this gradient became smaller over time. This effect is driven in particular by counties located in the Atlantic and Central states which together host $90 \%$ of our sample and where settlement was still ongoing and agriculture was the dominant income-generating activity. Before I explore the underlying time pattern in more detail, I conduct several robustness checks to provide further support to the main findings of the paper.

\subsection{Robustness checks}

\section{Shorter term rainfall variability}

The estimations above are based on county-specific rainfall variability calculated for the period 1895 to 1980 . I now re-estimate this model using county-decade-specific rainfall variability as specified in Equation (2), i.e. for each census year and each county I calculate the rainfall variability for the period starting five years prior to the census year and ending five years after the census year. Since rainfall data is only available for 1895 onwards, this specification does only use the census data of the years 1900-1930. The advantage of this specification is that it allows to use not only within-county variation between farm and nonfarm households but to use also within-county variation in rainfall variability across time. This should absorb further unobserved heterogeneity within counties. Table 6 shows the 
results: Col. (1) without rainfall-farm interactions, col. (2) with rainfall-farm interactions and col. (3) includes in addition state-specific time effects.

[Table 6 about here]

Again, I find that the overall effect of rainfall variability on fertility is positive (see col. (1)). As rainfall variability increases, rural households tend to have more children. Col. (2) shows that this effect is largely driven by farm households. Although the coefficient associated with rainfall variability is positive for both types of households the effect is three times larger for farm households. The difference between farm and non-farm households is about 0.5 which is similar to the difference identified above. If state-specific time effects are included, the linear coefficient turns insignificant and only the interaction effect with farm households stays significant. The size of the coefficient is 0.66 , this is also consistent with the order of magnitude identified above using the time-invariant measure of rainfall variability. Hence, overall these results support the findings above. Fertility in farm households increase with rainfall variability. This is not the case in non-farm households.

\section{Timing effects}

To further test the robustness of the results, I divided the sample into a subsample with all women younger than 25 years and a subsample with all women 25 years and older allowing to check whether the rainfall risk effect is only driven by younger women. This could be the case if in fact rainfall variability did not induce parents to have more children but only to have them earlier. Table 7 shows the estimated effect for two alternative specifications and both age groups. It turns out splitting the sample by women's age does not substantially alter the estimates. For both subsamples, higher rainfall variability is associated with higher fertility, but the effect is larger for the older age group. It is also only the older age group that shows the time pattern that was found for the total sample, i.e. a decrease of the risk effect over time. 
Overall, these results make it unlikely that the rainfall risk effect on fertility is only driven by women who have their children earlier.

\section{[Table 7 about here]}

\section{Rainfall risk-induced child mortality}

The results above would be biased if the increased fertility in counties with higher rainfall variability was partly a response to increased infant and child mortality induced by the rainfall variability. If droughts led to shortages of food and diseases that caused children to die more frequently, parents in counties with high rainfall variability may have increased their fertility to compensate. This mechanism has for instance been suggested by Kalemli-Ozcan (2003).

Unfortunately, mortality data for that period of time is scarce. Death registration procedures were universally in place only after 1933. Until 1910 deaths were only registered in the more industrialized and urbanized states of the Northeast. By 1900 about 26\% of the total population were covered and by 1910 about 51\%. After 1910, death registries were slowly introduced in the rest of the country (Pope, 2000). Based on the little data that existed, Haines (2008) estimates that the infant mortality rate for white people declined from 176 per 1000 live births in 1870, to 111 in 1900 and 60 in 1930 (Haines, 2008; see also Cutler and Meara, 2001). The general decline in mortality in the late nineteenth century was, in particular, the result of improvements in public health and sanitation (see, e.g., Cutler et al., 2006; Haines, 2008). Better diets, clothing and shelter also played a role. Medical interventions to curb specific infectious and parasitic diseases, including tuberculosis, pneumonia, bronchitis and gastro-intestinal infections, as well as lethal diseases such as cholera, smallpox, diphtheria, and typhoid fever led to significant mortality reductions only well into the twentieth century (Haines, 2008; Fishback et al., 2007). Malaria was a major cause of death until its eradication in 1950. Risks were high in the Southern and Southeastern regions and in the area along the Mississippi and Missouri Valleys and up through the Old Northwestern regions (Hong, 2007). 
With the data at hand, it is not possible to control for infant and child mortality systematically. However, there is little indication that mortality was highly correlated with rainfall variability. Mosquito breeding may increase with rainfall but the effect of rainfall variability on breeding is rather ambiguous. Droughts would certainly reduce breeding and hence reduce rather than increase mortality. Famines were very uncommon in the US at that time, given the abundant land resources. Even during the dust bowl of the 1930s, mortality did not reach levels that are typically associated with famines, yet it certainly led to significant income fluctuations (see, e.g., Worster, 1979; Hansen and Libecap, 2004). This makes it unlikely that rainfall variability led to higher fertility through increased mortality.

Moreover, if fertility increased in response to drought-induced child mortality, we would expect the effect not only to be present in farming households but in all rural households. The effect on non-agricultural households should in fact be larger, as they would be fully hit by the price increase in food staples caused by a supply shock. But what I find is the opposite, rainfall variance increases fertility among agricultural households but not among nonagricultural households.

Nevertheless, to further rule out that such a bias drives the results, I use the census data of 1900, where women were not only asked about the number of children in their household but were also asked to report the number of children ever born and the number of children that survived. I use these two variables to estimate child mortality rates per county and test whether child mortality was correlated with fertility, whether the mortality effect off-sets part of the rainfall variability effect and whether rainfall variability in turn can explain child mortality. Table 8 shows the results. Note that the county-specific mortality rate is computed separately for each woman such that her own experienced child mortality is not taken into account to avoid a potential endogeneity problem, though with a large number of women per county accounting or not accounting for a woman's own mortality does not really matter.

[Table 8 about here] 
Col. (1) in Table 8 re-estimates a simplified version of Equation (1) using the data of 1900 only and instead of using the number of children below five in the household it uses the number of children ever born as dependent variable. The differential effect of rainfall variability on fertility between farm and non-farm households is qualitatively similarly to the effects shown in Table 4. Col. (2) shows that increased child mortality does in fact not increase but decrease fertility, i.e. it seems that in counties with a high level of child mortality, mothers had rather less and not more children. An increase in the mortality rate by 10 percentage points would be associated with a decline in fertility by 0.2 children per mother. It is difficult to say from the data, why this is the case, but possibly maternal mortality was also higher in those counties and this may have reduced fertility. If as in col. (3) mortality and rainfall variability are introduced jointly, the effect of mortality is more or less unchanged and the effect of rainfall variability goes slightly up relative to the effect shown in Table 4. These results make it unlikely that the effect of rainfall variability is transmitted largely through rainfall risk-induced child mortality.

\section{Rainfall risk and returns to education}

Another potential concern is that differences in rainfall risk lead to differences in returns to education and, in consequence, also to returns to quantity. In this case the higher fertility was not the result of risk mitigation but the response to low returns to quality and hence high returns to quantity. This argument is not very different from the one tested in this paper as the underlying hypothesis is that rainfall-risk increases the return to quantity. Yet, to exclude that the effect only goes through education, I re-estimate Equation (1) controlling for children's school enrolment and I test whether higher rainfall variability is associated with higher school enrolment rates. The census data reports for each child in the household whether this child is

enrolled in school or not. In the second half of the $19^{\text {th }}$ century school enrollment rates for 5 to 19 -year olds fluctuated around $50 \%$ to $60 \%$ and started to rise from 1900 onwards quite 
rapidly. Since, older children are likely to have left the household already, I focus in what follows on the age group 6 to 14 . I calculate for each women the share of her children in that age group that is enrolled in school. Table 9 shows the results. The comparison of cols. (1), (2) and (3) shows that the effect of rainfall risk on farm households' fertility is not significantly changed if school enrolment is among the controls. School enrolment itself is negatively correlated with fertility as the quality-quantity trade-off model predicts. Rainfall variability in turn is associated with a lower enrolment rates. But the effect is relatively small. A shift from the tenth to the ninetieth percentile in the rainfall risk distribution is associated with an increase in the difference in school enrolment rates between farm and non-farm households by a mere 1.7 percentage points. Based on these findings it is unlikely that the effect of rainfall variability on fertility dominantly passes through reduced educational investments.

\section{[Table 9]}

\subsection{The effect of risk-mitigating technologies and institutions}

The results above suggest that the effect of rainfall risk on fertility is reduced as time progresses. In this section I test whether this phasing out can be explained by the adoption of risk-mitigating technologies or the emergence of risk-mitigating institutions. I focus on the adoption of irrigation systems, the use of physical capital more generally and the spread of formal banks. For all three it can be argued that they reduce the need of parents to have many children to cope with rainfall risks. Unfortunately, data for the availability of irrigation systems and formal banks is only available for selected years: irrigation data at the county level is available for the period 1900 and 1910; data on banks is available for the years 1920 and 1930. The following maps (Figures 5-7) show the spatial distribution of irrigation systems, agricultural machinery and banks over time.

[Figures 5-7 about here] 
Figure 5 shows that irrigation was used particularly, as one might expect, in the arid West, but also spread to the western and southern parts of the Central region as time progressed. The use of machinery increased rapidly at the beginning of the twentieth century, in particular in the Great Plains (Fig. 6). This can be explained by a number of innovations that became available for large scale adoption, such as tractors and reapers. It is also due to the ongoing electrification which started in 1880, and the increasing availability of credit, both of which made it possible for households to use more machinery. Banks are in particular concentrated in New England and the northeastern Central states. As a consequence of the 1929 financial crisis there are fewer banks in 1930 than in 1920 (Fig. 7). In 1929 and 1930 alone almost 2,000 banks failed, mainly due to a run on banks during which millions of depositors throughout the country withdrew their savings (Wicker, 1996; Klein 2001).

To test for the effect of risk-mitigating technologies (I), I estimate Equation (3). Table 10 shows the results. Cols. (1) and (2) show that the effect of rainfall risk on fertility is significantly reduced for women in farming households in counties where farms adopted irrigation systems when compared to counties where irrigation systems were not available. The size of the estimated coefficients in col. (2) implies that the fertility differential due to rainfall variability between farm and non-farm households disappears if the share of irrigated land in a county exceeds $50 \%$. The fertility effect is also lower in counties where more machinery is used. Table 10 (col. (4)) shows, that the fertility differential shrinks by almost 40 percent if counties in the ninetieth percentile of the distribution of machinery are compared with counties in the tenth percentile. Finally, cols. (5) and (6) show the results where rainfall variability is interacted with the access to financial services. Although the sign of this interaction is also negative, the effect is economically and statistically insignificant. The results do not change much whether the absolute number of banks per county or the number of banks per farm per county are considered. Hence, based on this specification it is hard to say whether financial services could not or were not used for risk coping or whether the 
available measures of access to financial services are simply not adequate. Yet, overall the results in Table 10 seem to support the idea that farming households used children to insure themselves against rainfall shocks but that this effect disappeared as other risk-mitigating technologies became available, at least this seems to be the case for irrigation and machinery. ${ }^{8}$ In contrast to rainfall risk, I do not find strong effects between rainfall levels, fertility and risk-mitigating technologies.

The results in this section could of course be biased if the emergence of these risk-mitigating technologies and services was endogenous to fertility decisions. These and other threats to identification are discussed in the following section.

[Table 10 about here]

\subsection{Remaining threats to identification}

\section{Endogenous migration}

The results presented above could be biased if unobserved preferences determined both the destination of settlers and fertility, i.e. if parents with a preference for fewer children migrated systematically to areas with lower rainfall variability. Dunlevy (1980) and Dunlevy and Saba (1992) highlight four factors explaining the choice of destination of settlers in the nineteenth century: population density, the availability of land, the distance to the port of entry and prevailing per capita income. The latter was generally seen as an indicator of expected income or job opportunities. Gallaway et al. (1974) provide some evidence that native-born Americans tended to migrate to the less densely populated states whereas immigrants were more inclined to locate in the more densely populated states. The presence of friends and relatives was also an attraction to immigrants (Gallaway et al., 1974). According to Dunlevy (1980), the exact weather conditions played only a minor role (see also Dunlevy and Saba,

\footnotetext{
${ }^{8}$ Guest and Tolnay (1985) show that in the early 1900s, increasing farm mechanization increased education investment suggesting that mechanization reduced the return on child labor.
} 
1992). He shows that, if anything, some migrants were attracted by destinations that showed a climate similar to the one they had in their home country. All this is of course not enough to rule out the potential concerns about endogeneity, but at least there is nothing that explicitly suggests that, conditional on other geographic characteristics including rainfall levels, rainfall variance was an important determinant for the destination choice of immigrants and nativeborn migrants.

\section{Endogenous adoption of irrigation systems, machinery and placement of banks}

The analysis on the effect of the emergence of risk-mitigating technologies and services on fertility may also suffer from endogeneity problems. This would be the case if, for instance, farming households with a preference for fewer children sorted themselves into areas where risk-mitigating technologies and institutions were available or if they at least, adopted these technologies and institutions earlier than others. The emergence of irrigation systems and financial services and the use of machinery could also be correlated with the county-specific quality and suitability of land for agricultural production and where both are high, parents have fewer children. Finally, the emergence of irrigation systems and financial services could also be correlated with the emergence of other types of infrastructure and institutions that in turn also affected fertility. The used controls can only imperfectly account for such unobserved heterogeneity.

\section{Conclusion}

This paper explored the role of rainfall risk in the American demographic transition. Risk exposure has so far only received little attention as a driver of fertility. My findings provide some support for the hypothesis that in a context in which formal insurance devices are largely absent, fertility may respond to a need to insure risks. I find that in the late nineteenth century in the United States, agricultural households that were exposed to extreme rainfall 
variability, controlling for rainfall levels, had higher fertility than agricultural households that were exposed to lower levels of rainfall variability. As expected, rainfall variability does not affect fertility in non-agricultural households. This effect is robust to a wide range of controls including county fixed effects and state-specific time effects. Going from the tenth to the ninetieth percentile in the distribution of rainfall variability increases the fertility differential between farm and non-farm households by about 25 percent in the late $19^{\text {th }}$ century. Focusing just on the Atlantic and Central states, the effects are even greater. Interestingly, the effect decreases over time, in particular in the early twentieth century, suggesting that the insurance function of children is diluted as more capital is used in agriculture and alternative risk management devices emerge. And indeed, using data on the use of irrigation systems and agricultural machinery as well as data on the access to banks, it can be shown that the fertility effect decreases as these aspects gain importance, although for access to banks the effect is very small. The observational character of the data and other data limitations do not allow me to deal with all possible confounding factors and hence the findings are not necessarily causal, but they are quite robust to alternative specifications and lead, overall, to a consistent story. I can in particular show that the effects are not driven by rainfall variability-induced child mortality or a quantity-quality trade off triggered by differences in the returns to education between areas with low and high rainfall variability.

The findings from this paper cannot only contribute to a better understanding of the demographic transition in the USA, they can also enrich demand-side theory of fertility and models of long-term growth with endogenous population. The findings also have potentially important implications for Sub-Saharan Africa, where, in most regions, households are exposed to significant risks. Households have to cope with rainfall shortages, crop diseases, price shocks, natural disasters, health shocks and conflicts. As formal risk management devices are usually absent, these risks may partly drive fertility and keep it at high levels. It may explain why, in some regions, and in particular in poor rural semi-arid or arid areas of 
Sub-Saharan Africa, the demographic transition has often not even started or, if it has started, progresses only slowly or has stalled (Bongaarts and Casterline, 2013).

\section{Appendix}

Definition of regions

[Figure A.1 here]

The effect of rainfall and rainfall variability on agricultural production

[Table A.1 here]

\section{References}

Ager, P. and A. Ciccone (2014), Rainfall Risk and Religious Membership in the Late Nineteenth-Century United States, Working Paper \#14-20, University of Mannheim.

Ager, P., M. Bruckner and B. Herz (2015), Agricultural Income and Fertility. Mimeo.

Aaronson, D., F. Lange and B. Mazumder (2014), Fertility Transitions along the Extensive and Intensive Margins. American Economic Review, 104 (11): 3701-24.

Basso, A., H. Bodenhorn and D. Cuberes (2014), Fertility and Financial Development: Evidence from U.S. Counties in the $19^{\text {th }}$ Century. NBER Working Paper \#20491, NBER, Cambridge, M.A.

Becker, S.O., F. Cinnirella and L. Woessmann (2013), Does women's education affect fertility? Evidence from pre-demographic transition Prussia. European Review of Economic History, 17(1), pp. 24-44.

Bleakley, H. and F. Lange (2009), Chronic Disease Burden and the Interaction of Education, Fertility, and Growth. Review of Economics and Statistics, 91 (1), 52-65.

Bongaarts, J. and J. Casterline (2013), Fertility Transition: Is sub-Saharan Africa Different? Population and Development Review, 38 (s1): 153-168. 
Cain, M. (1981), Risk and Insurance: Perspectives on Fertility and Agrarian Change in India and Bangladesh. Population and Development Review, 7 (3), 435-474.

Cain, M. (1983), Fertility as an adjustment to risk. Population and Development Review, 9 (4): 688-702.

Cain, M. (1986), Risk and Fertility: A Reply to Robinson. Population Studies, 40: 299-304.

Cain, M. (1990), Risk and Fertility in a Semi-Feudal Context: The Case of Rural Madhya Pradesh. Research Division Working Paper 19, Center for Policy Studies: New York.

Caldwell, J.C. (1982), A Theory of Fertility Decline. New York: Academic Press.

Cutler, D.M., A. Deaton and A. Lleras-Muney (2006), The Determinants of Mortality. Journal of Economic Perspectives. 20 (3): 97-120.

Cutler, D.M. and E. Meara (2001), Changes in the Age Distribution of Mortality Over the $20^{\text {th }}$ Century. NBER Research Working Paper \#8556, National Bureau of Economic Research, Cambridge, M.A.

Dasgupta, P. (1995), The Population problem: Theory and Evidence. Journal of Economic Literature, 1879-1902.

Dempster, G.M., and J.P. Isaacs (2014), Structural Change in the U.S. Economy: 1850-1900. Structural Change and Economic Dynamics, 31: 112-123.

De Vany, A. and N. Sanchez (1979), Land Tenure Structures and Fertility in Mexico. Review of Economics and Statistics, 61 (1): 67-72.

Dimitri, C., A. Effland and N. Conklin (2005), The 20 ${ }^{\text {th }}$ Century Transformation of U.S. Agriculture and Farm Policy. Economic Information Bulletin No. 3, Economic Research Service, United States Department of Agriculture.

Dunlevy, J.A. (1980), Nineteenth-Century European Immigration to the United States: Intended versus Lifetime Settlement Patterns. Economic Development and Cultural Change, 29 (1): 77-90. 
Dunlevy, J.A. and R.P. Saba (1992), The Role of Nationality-Specific Characteristics on the Settlement Patterns of Late Nineteenth Century Immigrants. Explorations in Economic History, 29: 228-249.

Duryea, S., D. Lam and D. Levison (2007), Effects of economic shocks on children's employment and schooling in Brazil. Journal of Development Economics, 84 (1): 188214.

Easterlin, R.A. (1976), Population change and farm settlement in the northern United States. Journal of Economic History, 36 (1): 45 - 75.

Easterlin, R.A. (2000). Growth and composition of the American population in the twentieth century. In Haines, M. R. (ed.), A Population History of North America (pp. 631 - 677). Cambridge University Press, Cambridge.

Edmonds, E.V. (2006), Child labor and schooling responses to anticipated income in South Africa. Journal of Development Economics, 81 (2): 386-414.

Ehrlich, I. and F.T. Lui (1991), Intergenerational Trade, Longevity, and Economic Growth. Journal of Political Economy, 99 (5): 1029-59.

Fishback, P.V., M.R. Haines and S. Kantor (2007), Births, Deaths, and the New Deal Relief During the Great Depression. The Review of Economics and Statistics, 89 (1): 1-14.

Forster, C. and G. Tucker (1972). Economic Opportunity and White American Fertility Ratios. Yale University Press, New Haven.

Gallaway, L.E., R.K. Vedder and V. Shukla (1974), The distribution of the immigrant population in the United States: an economic analysis. Explorations in Economic History, 11 (3): 213-226.

Galor, O. (2012), The demographic transition: causes and consequences. Cliometrica, 6: 1-28. Galor, O. and O. Moav (2002), Natural selection and the origin of economic growth. Quarterly Journal of Economics, 117 (4): 1133-1191. 
Galor, O. and D. Weil (2000), Population, Technology and Growth: From Malthusian Stagnation to the Demographic Transition and Beyond. American Economic Review, 90, 806-828.

Greenwood, J. and A. Seshadri (2002). The U.S. demographic transition. American Economic Review, 92(2):153 - 159.

Guest, A.M. and S. E. Tolnay (1985), Agricultural Organization and Education Consumption in the U.S. in 1900. Sociology of Education, 58: 201-212.

Hacker, D. (2003), Rethinking the early decline of marital fertility in the United States. Demography, 40(4): $505-620$.

Haines, M. (2000), The white population of the United States, 1790 - 1920. In Steckel, R. (ed.), A Population History of North America (pp. 305 - 371), Cambridge University Press, Cambridge.

Haines, M. R. and Hacker, D. (2006), The puzzle of the antebellum fertility decline in the United States. New evidence and reconsideration. Technical Report 12571, NBER Working Paper.

Haines, M.R. (2008), Fertility and Mortality in the United States. In R. Whaples, EH.Net Encyclopedia (https://eh.net/encyclopedia/).

Hansen C.W. and P.S. Jensen and L. Lønstrup (2014), The Fertility Transition in the US: Schooling or Income? Economics Working Papers 2014-02, Aarhus University.

Hansen, Z.K. and G.D. Libecap (2004), Small farms, externalities, and the dust bowl of the 1930s. Journal of Political Economy, 112 (3): 665-694.

Herweijer, C., R. Seager and E.R. Cook (2006), North American droughts of the mid to late nineteenth century: a history, simulation and implication for Mediaeval drought. The Holocene, 16 (2): 159-171.

Hong, S.C. (2007), The Burden of Early Exposure to Malaria in the United States, 1850-1860: Malnutrition and Immune Disorders. Journal of Economic History, 67 (4): 1001-1035. 
Horan P.M. and P.G. Hargis (1991), Children's Work and Schooling in the Late NineteenthCentury Family Economy. American Sociological Review, 56 (5): 583-596.

Jensen, E.R. (1990), An econometric analysis of the old-age security motive for child-bearing. International Economic Review 31, (4): 953-968.

Johnson, K. M. and R.W. Rathge (2006). Agricultural dependence and changing population in the great plains. In Population change and rural society (pp. 197-217), Springer.

Jones, L. E. and M. Tertilt (2006). An Economic History of Fertility in the U.S. NBER Working Paper \#12796, NBER, Cambridge, M.A.

Kalemli-Ozcan, S. (2003), A stochastic model of mortality, Fertility and Human Capital Investment, Journal of Development Economics, 70 (3): 101-118.

Klein, M. (2001). Rainbow's End: The Crash of 1929. New York: Oxford University Press.

Landmann, A. and M. Frölich (2015), Can health-insurance help prevent child labor? An impact evaluation from Pakistan. Journal of Health Economics, 39(C): 51-59.

Lahey, J.N. (2014), The Effect of Anti-Abortion Legislation on Nineteenth Century Fertility, Demography, 51(3): 939-948.

Neher, P.A. (1971), Peasants, Procreation and Pensions. American Economic Review, (61): 380-389.

Nugent, J.B. (1985), The old-age security motive for fertility. Population and Development Review, 11 (1): 75-97.

Perelman, M. (1973), Mechanization and the Division of Labor in Agriculture. American Journal of Agricultural Economics, 55 (3): 523-526.

Pope, C.L. (2000), Adult Mortality in America before 1900. A View from Family Histories. In M.R. Haines and R.H. Steckel, A Population History of North America. Cambridge: Cambridge University Press.

Pörtner, C.C. (2001), Children as Insurance, Journal of Population Economics, 14: 119-136. 
Pörtner, C.C. (2011), Gone with the Wind? Hurricane Risk, Fertility and Education. Mimeo, Seattle University.

Rendall, M.S. and R.A. Bahchieva (1998), An Old-Age Security Motive for Fertility in the United States? Population and Development Review, 24: 293-307.

Thompson, W. S. and P. Whelpton (1933). Population Trends in the United States. McGrawHill.

US Department of Labor (1968), Child Labor Laws Historical Development, US Department of Labor Washington, U.S.

Vinovskis, M.A. (1976), Socioeconomic Determinants of Interstate Fertility Differentials in the United States in 1850 and 1860. The Journal of Interdisciplinary History, 6 (3): 375-396.

Walters, P.B and P.J. O’Connell (1988), The family economy, work, and educational participation in the United States, 1890. American Journal of Sociology, 93:1116-1152.

Wicker, E. (1996), The Banking Panics of the Great Depression. Cambridge University Press, New York.

Willis, R. J. (1980), The old age security and population growth, in Demographic behavior: Interdisciplinary perspectives on decision making, ed. by T. K. Burch. Westview Press, Boulder, CO.

Worster, D. (1979). Dust Bowl: The Southern Plains in the 1930s. Oxford University Press, New York.

Yasuba, Y. (1962). Birth rates of the white population in the United States. $1800-1860$. An Economic Study. John Hopkins University Press, Baltimore. 
Tables

Table 1. Sample composition

\begin{tabular}{lrrrrrrr}
\hline & \multicolumn{1}{c}{1870} & \multicolumn{1}{c}{1880} & \multicolumn{1}{c}{1900} & \multicolumn{1}{c}{1910} & 1920 & \multicolumn{1}{c}{1930} & \multicolumn{1}{c}{ Total } \\
\hline Women (15-39) & 42,968 & 554,928 & 334,439 & 73,808 & 75,285 & 379,326 & $1,460,754$ \\
Share obs. & 0.029 & 0.380 & 0.229 & 0.051 & 0.052 & 0.260 & 1 \\
Counties & 1,821 & 2,121 & 2,465 & 2,626 & 2,751 & 2,787 & 14,571 \\
States & 36 & 38 & 44 & 46 & 48 & 48 & 260 \\
\hline
\end{tabular}

Notes: white, rural population excluding Alaska, Hawaii and people living in military camps.

Source: US population census (IPUMS).

Table 2. Descriptive statistics, all states, over time

\begin{tabular}{|c|c|c|c|c|c|c|}
\hline & 1870 & 1880 & 1900 & 1910 & 1920 & 1930 \\
\hline \# children under five & 0.616 & 0.617 & 0.579 & 0.586 & 0.570 & 0.509 \\
\hline Age & 25.1 & 25.3 & 25.4 & 25.6 & 25.9 & 25.8 \\
\hline Literate & 0.862 & 0.900 & 0.942 & 0.959 & 0.969 & 0.979 \\
\hline Head literate & 0.868 & 0.888 & 0.914 & 0.927 & 0.937 & 0.945 \\
\hline Farm hh & 0.573 & 0.592 & 0.600 & 0.568 & 0.585 & 0.535 \\
\hline Av. value farml. \& build. p/a ${ }^{a}$ & 19.8 & 17.1 & 21.1 & 41.1 & 74.1 & 56.9 \\
\hline Av. farmland per farm $\left.{ }^{a}\right)$ & 205.2 & 177.3 & 283.1 & 260.5 & 284.9 & 306.8 \\
\hline Av. value of impl. \& machin. per farm ${ }^{\mathrm{a})}$ & 115.9 & 94.6 & 140.6 & 220.7 & 618.8 & 611.7 \\
\hline Share of land irrigated ${ }^{\text {a) }}$ & & & 0.043 & 0.053 & & \\
\hline Number of banks ${ }^{\text {a) }}$ & & & & & 9.8 & 7.0 \\
\hline
\end{tabular}

Notes: ${ }^{\text {a) }}$ County averages (values in constant US dollar, surface in acres).

Source: US population census, agricultural census (IPUMS, NHGIS); own estimations.

Table 3. Descriptive statistics, by region, 1880 and 1930

\begin{tabular}{|c|c|c|c|c|c|c|c|c|}
\hline & \multicolumn{2}{|c|}{ New England } & \multicolumn{2}{|c|}{ Atlantic states } & \multicolumn{2}{|c|}{ Central states } & \multicolumn{2}{|c|}{ Mountains/Pacific } \\
\hline & 1880 & 1930 & 1880 & 1930 & 1880 & 1930 & 1880 & 1930 \\
\hline \# children under five & 0.399 & 0.472 & 0.589 & 0.516 & 0.655 & 0.510 & 0.611 & 0.484 \\
\hline Age & 25.9 & 26.4 & 25.4 & 25.8 & 25.2 & 25.7 & 25.7 & 26.1 \\
\hline Literate & 0.945 & 0.989 & 0.883 & 0.977 & 0.902 & 0.981 & 0.951 & 0.972 \\
\hline Head literate & 0.910 & 0.960 & 0.872 & 0.929 & 0.892 & 0.952 & 0.932 & 0.947 \\
\hline Farm hh & 0.273 & 0.360 & 0.507 & 0.400 & 0.675 & 0.614 & 0.376 & 0.446 \\
\hline Av. value farml. \& build. p/a ${ }^{a}$ & 34.1 & 86.3 & 19.8 & 55.1 & 15.8 & 68.1 & 13.6 & 42.6 \\
\hline Av. farmland per farm ${ }^{a}$ & 105.9 & 116.0 & 161.3 & 305.4 & 172.5 & 96.2 & 370.0 & 709.2 \\
\hline $\begin{array}{l}\text { Av. value of impl. \& machin. } \\
\text { per farm }{ }^{\text {a) }}\end{array}$ & 117.0 & 694.1 & 74.2 & 631.4 & 94.2 & 378.5 & 208.4 & 917.0 \\
\hline Share of total observations & 0.065 & 0.013 & 0.305 & 0.288 & 0.608 & 0.614 & 0.022 & 0.086 \\
\hline
\end{tabular}

Notes: ${ }^{\text {a) }}$ County averages (values in US dollar, surface in acres).

Source: US population census, agricultural census (IPUMS, NHGIS); own estimations. 
Table 4. The effect of rainfall variability on fertility, main results

\begin{tabular}{|c|c|c|c|c|c|c|c|c|}
\hline & $\begin{array}{c}(1) \\
\text { OLS }\end{array}$ & $\begin{array}{c}(2) \\
\text { Basic FE }\end{array}$ & $\begin{array}{c}(3) \\
\text { Big counties }\end{array}$ & $\begin{array}{c}(4) \\
\text { Year interact. }\end{array}$ & $\begin{array}{c}\quad(5) \\
\text { State-time FE }\end{array}$ & $\begin{array}{c}(6) \\
\text { Drought }\end{array}$ & $\begin{array}{l}\text { (7) } \\
\text { Rural \& Urb. }\end{array}$ & $\begin{array}{c}(8) \\
\text { Aggregated }\end{array}$ \\
\hline Age group 15-19 & Ref. & Ref. & Ref. & Ref. & Ref. & Ref. & Ref. & Ref. \\
\hline Age group 20-24 & $\begin{array}{c}0.510 * * * \\
(0.004)\end{array}$ & $\begin{array}{c}0.499 * * * \\
(0.003)\end{array}$ & $\begin{array}{c}0.498 * * * \\
(0.003)\end{array}$ & $\begin{array}{c}0.499 * * * \\
(0.003)\end{array}$ & $\begin{array}{c}0.500 * * * \\
(0.003)\end{array}$ & $\begin{array}{c}0.500 * * * \\
(0.003)\end{array}$ & $\begin{array}{c}0.422 * * * \\
(0.007)\end{array}$ & $\begin{array}{c}0.378 * * * \\
(0.025)\end{array}$ \\
\hline Age group 25-29 & $\begin{array}{c}0.848 * * * \\
(0.005)\end{array}$ & $\begin{array}{c}0.852 * * * \\
(0.004)\end{array}$ & $\begin{array}{c}0.852 * * * \\
(0.004)\end{array}$ & $\begin{array}{c}0.852 * * * \\
(0.004)\end{array}$ & $\begin{array}{c}0.852 * * * \\
(0.004)\end{array}$ & $\begin{array}{c}0.852 * * * \\
(0.004)\end{array}$ & $\begin{array}{c}0.736 * * * \\
(0.009)\end{array}$ & $\begin{array}{c}0.488 * * * \\
(0.025)\end{array}$ \\
\hline Age group 30-34 & $\begin{array}{c}0.786 * * * \\
(0.005)\end{array}$ & $\begin{array}{c}0.806 * * * \\
(0.004)\end{array}$ & $\begin{array}{c}0.807 * * * \\
(0.004)\end{array}$ & $\begin{array}{c}0.806 * * * \\
(0.004)\end{array}$ & $\begin{array}{c}0.807 * * * \\
(0.004)\end{array}$ & $\begin{array}{c}0.807 * * * \\
(0.004)\end{array}$ & $\begin{array}{c}0.695 * * * \\
(0.007)\end{array}$ & $\begin{array}{c}0.575^{* * * *} \\
(0.033)\end{array}$ \\
\hline Age group 35-39 & $\begin{array}{c}0.627 * * * \\
(0.004)\end{array}$ & $\begin{array}{c}0.648 * * * \\
(0.004)\end{array}$ & $\begin{array}{c}0.649 * * * \\
(0.004)\end{array}$ & $\begin{array}{c}0.648 * * * \\
(0.004)\end{array}$ & $\begin{array}{c}0.649 * * * \\
(0.004)\end{array}$ & $\begin{array}{c}0.649 * * * \\
(0.004)\end{array}$ & $\begin{array}{c}0.542 * * * \\
(0.006)\end{array}$ & $\begin{array}{c}0.478 * * * \\
(0.080)\end{array}$ \\
\hline Literate & $\begin{array}{c}-0.165^{* * *} \\
(0.008)\end{array}$ & $\begin{array}{c}-0.131^{* * *} \\
(0.006)\end{array}$ & $\begin{array}{c}-0.131^{* * *} \\
(0.006)\end{array}$ & $\begin{array}{c}-0.132 * * * \\
(0.006)\end{array}$ & $\begin{array}{c}-0.137 * * * \\
(0.006)\end{array}$ & $\begin{array}{c}-0.137 * * * \\
(0.006)\end{array}$ & $\begin{array}{c}-0.204^{* * *} \\
(0.010)\end{array}$ & $\begin{array}{c}-0.183^{* * *} \\
(0.039)\end{array}$ \\
\hline Literate head & $\begin{array}{c}0.033 * * * \\
(0.005)\end{array}$ & $\begin{array}{c}0.042 * * * \\
(0.004)\end{array}$ & $\begin{array}{c}0.042 * * * \\
(0.004)\end{array}$ & $\begin{array}{c}0.042 * * * \\
(0.004)\end{array}$ & $\begin{array}{c}0.041 * * * \\
(0.004)\end{array}$ & $\begin{array}{c}0.042^{* * *} \\
(0.004)\end{array}$ & $\begin{array}{c}0.062 * * * \\
(0.004)\end{array}$ & $\begin{array}{l}0.076 * * \\
(0.033)\end{array}$ \\
\hline Farm hh & $\begin{array}{c}0.093 \\
(0.059)\end{array}$ & $\begin{array}{l}-0.066 \\
(0.050)\end{array}$ & $\begin{array}{l}-0.094 * \\
(0.052)\end{array}$ & $\begin{array}{l}-0.053 \\
(0.051)\end{array}$ & $\begin{array}{l}-0.048 \\
(0.048)\end{array}$ & $\begin{array}{c}-0.093 * * * \\
(0.032)\end{array}$ & $\begin{array}{l}-0.008 \\
(0.045)\end{array}$ & $\begin{array}{c}0.014 \\
(0.065)\end{array}$ \\
\hline Val. land and build. p.a. (ln) & $\begin{array}{c}-0.048 * * * \\
(0.005)\end{array}$ & $\begin{array}{c}-0.085^{* * *} \\
(0.005)\end{array}$ & $\begin{array}{c}-0.086^{* * *} \\
(0.005)\end{array}$ & $\begin{array}{c}-0.078 * * * \\
(0.005)\end{array}$ & $\begin{array}{c}-0.024 * * * \\
(0.007)\end{array}$ & $\begin{array}{c}-0.025^{* * *} \\
(0.007)\end{array}$ & $\begin{array}{l}-0.003 \\
(0.008)\end{array}$ & $\begin{array}{c}-0.030 * * \\
(0.012)\end{array}$ \\
\hline Av. farm size (ln) & $\begin{array}{l}-0.012 * \\
(0.007)\end{array}$ & $\begin{array}{c}-0.101^{* * *} \\
(0.008)\end{array}$ & $\begin{array}{c}-0.103^{* * *} \\
(0.008)\end{array}$ & $\begin{array}{c}-0.098 * * * \\
(0.008)\end{array}$ & $\begin{array}{c}-0.040 * * * \\
(0.009)\end{array}$ & $\begin{array}{c}-0.036^{* * *} \\
(0.009)\end{array}$ & $\begin{array}{c}-0.018 * \\
(0.010)\end{array}$ & $\begin{array}{c}-0.035^{* *} \\
(0.014)\end{array}$ \\
\hline Av. value machinery (ln) & $\begin{array}{c}-0.049 * * * \\
(0.007)\end{array}$ & $\begin{array}{c}0.027 * * * \\
(0.006)\end{array}$ & $\begin{array}{c}0.027 * * * \\
(0.007)\end{array}$ & $\begin{array}{c}0.027 * * * \\
(0.006)\end{array}$ & $\begin{array}{c}0.006 \\
(0.007) \\
\end{array}$ & $\begin{array}{c}0.004 \\
(0.007) \\
\end{array}$ & $\begin{array}{l}-0.009 \\
(0.009)\end{array}$ & $\begin{array}{c}0.025 * * \\
(0.012)\end{array}$ \\
\hline
\end{tabular}


Table continued

\begin{tabular}{|c|c|c|c|c|c|c|c|c|}
\hline Rainfall (ln) & $\begin{array}{l}-0.020^{*} \\
(0.011)\end{array}$ & & & & & & & \\
\hline Var Rainfall (ln) & $\begin{array}{c}-0.196 * * * \\
(0.068)\end{array}$ & & & & & & & \\
\hline Var rainfall (ln) x Farm hh & $\begin{array}{c}0.373^{* * *} \\
(0.101)\end{array}$ & $\begin{array}{c}0.509^{* * *} \\
(0.084)\end{array}$ & $\begin{array}{c}0.547^{* * *} \\
(0.088)\end{array}$ & $\begin{array}{c}1.035 * * * \\
(0.167)\end{array}$ & $\begin{array}{c}0.932 * * * \\
(0.207)\end{array}$ & $\begin{array}{c}1.228^{* * *} \\
(0.179)\end{array}$ & $\begin{array}{c}0.758^{* * *} \\
(0.196)\end{array}$ & $\begin{array}{c}0.501^{* *} \\
(0.252)\end{array}$ \\
\hline Rainfall (ln) x Farm hh x 1900 & & & & $\begin{array}{c}0.011^{* * *} \\
(0.003)\end{array}$ & $\begin{array}{c}0.007^{* *} \\
(0.003)\end{array}$ & $\begin{array}{l}0.006^{*} \\
(0.003)\end{array}$ & $\begin{array}{c}0.016^{* * *} \\
(0.003)\end{array}$ & $\begin{array}{c}0.001 \\
(0.004)\end{array}$ \\
\hline Rainfall (ln) x Farm hh x 1910 & & & & $\begin{array}{c}0.013^{* * *} \\
(0.003)\end{array}$ & $\begin{array}{c}0.008^{* *} \\
(0.003)\end{array}$ & $\begin{array}{c}0.006 \\
(0.004)\end{array}$ & $\begin{array}{c}0.018 * * * \\
(0.003)\end{array}$ & $\begin{array}{c}0.000 \\
(0.005)\end{array}$ \\
\hline Rainfall (ln) x Farm hh x 1920 & & & & $\begin{array}{c}0.017 * * * \\
(0.003)\end{array}$ & $\begin{array}{c}0.015^{* * *} \\
(0.003)\end{array}$ & $\begin{array}{c}0.014^{* * *} \\
(0.004)\end{array}$ & $\begin{array}{c}0.022 * * * \\
(0.003)\end{array}$ & $\begin{array}{c}0.004 \\
(0.005)\end{array}$ \\
\hline Var rainfall (ln) x Farm hh x 1900 & & & & $\begin{array}{c}-0.475^{* * *} \\
(0.144)\end{array}$ & $\begin{array}{c}-0.440^{* *} \\
(0.182)\end{array}$ & $\begin{array}{l}-0.292 \\
(0.182)\end{array}$ & $\begin{array}{l}-0.266 \\
(0.168)\end{array}$ & $\begin{array}{l}-0.259 \\
(0.243)\end{array}$ \\
\hline Var rainfall (ln) x Farm hh x 1910 & & & & $\begin{array}{c}-0.456 * * * \\
(0.169)\end{array}$ & $\begin{array}{l}-0.327 \\
(0.200)\end{array}$ & $\begin{array}{l}-0.165 \\
(0.203)\end{array}$ & $\begin{array}{l}-0.167 \\
(0.194)\end{array}$ & $\begin{array}{l}-0.189 \\
(0.268)\end{array}$ \\
\hline Var rainfall (ln) x Farm hh x 1920 & & & & $\begin{array}{c}-0.719 * * * \\
(0.164)\end{array}$ & $\begin{array}{c}-0.533^{* * *} \\
(0.200)\end{array}$ & $\begin{array}{c}-0.401^{* *} \\
(0.195)\end{array}$ & $\begin{array}{l}-0.356^{*} \\
(0.197)\end{array}$ & $\begin{array}{l}-0.093 \\
(0.287)\end{array}$ \\
\hline Var rainfall (ln) x Farm hh x 1930 & & & & $\begin{array}{c}-0.826^{* * *} \\
(0.160) \\
\end{array}$ & $\begin{array}{c}-0.637^{* * *} \\
(0.197) \\
\end{array}$ & $\begin{array}{c}-0.547^{* * *} \\
(0.183) \\
\end{array}$ & $\begin{array}{c}-0.505^{* * *} \\
(0.193) \\
\end{array}$ & $\begin{array}{l}-0.326 \\
(0.247) \\
\end{array}$ \\
\hline
\end{tabular}


Table continued

\begin{tabular}{|c|c|c|c|c|c|c|c|c|}
\hline County fixed effects & & Yes & Yes & Yes & Yes & Yes & Yes & Yes \\
\hline Time fixed effects & Yes & Yes & Yes & Yes & & & & \\
\hline State-specific time effects & No & No & No & No & Yes & Yes & Yes & Yes \\
\hline R-squared & 0.157 & 0.158 & 0.158 & 0.158 & 0.160 & 0.160 & 0.135 & 0.154 \\
\hline Observations & $1,460,688$ & $1,460,754$ & $1,435,796$ & $1,460,754$ & $1,460,754$ & $1,460,754$ & $2,489,123$ & 26,492 \\
\hline Counties & 2,793 & 2,793 & 2,441 & 2,793 & 2,793 & 2,793 & 2,799 & 2,441 \\
\hline
\end{tabular}

Notes: $* * * \mathrm{p}<0.01,{ }^{* *} \mathrm{p}<0.05, * \mathrm{p}<0.1$. "OLS" does not include county fixed effects. "Basic FE” includes county fixed effects and time effects. "Big counties" excludes countie with less than 30 observations from the sample. "Year interact." includes Rainfall-farm household-year interactions". "State-fime FE" includes state-specific time effects. "Drought” uses the probability of a drought as a measure of rainfall variance. "Rural \& urban” includes also urban households into the sample. "Aggregated” uses county averages for estimation.

Source: US population census, agricultural census (IPUMS, NHGIS); PRISM Precipitation dataset; own estimations. 
Table 5. The effect of rainfall variability on fertility, by region

\begin{tabular}{|c|c|c|c|c|c|c|c|c|}
\hline & $\begin{array}{c}(1) \\
\text { New Engl. }\end{array}$ & $\begin{array}{c}(2) \\
\text { New Engl. }\end{array}$ & $\begin{array}{c}\text { (3) } \\
\text { Atlantic }\end{array}$ & $\begin{array}{c}(4) \\
\text { Atlantic }\end{array}$ & $\begin{array}{c}(5) \\
\text { Central }\end{array}$ & $\begin{array}{c}(6) \\
\text { Central }\end{array}$ & $\begin{array}{c}\text { (7) } \\
\text { Mount./Pac. }\end{array}$ & $\begin{array}{c}\text { (8) } \\
\text { Mount./Pac. }\end{array}$ \\
\hline Rainfall (ln) x Farm hh & $\begin{array}{c}0.146 \\
(0.192)\end{array}$ & $\begin{array}{c}0.175 \\
(0.187)\end{array}$ & $\begin{array}{c}0.251^{* * *} \\
(0.068)\end{array}$ & $\begin{array}{c}0.207^{* * * *} \\
(0.068)\end{array}$ & $\begin{array}{l}-0.023^{*} \\
(0.013)\end{array}$ & $\begin{array}{c}-0.054^{* * *} \\
(0.013)\end{array}$ & $\begin{array}{c}-0.022^{*} \\
(0.013)\end{array}$ & $\begin{array}{l}-0.038 \\
(0.052)\end{array}$ \\
\hline Var rainfall (ln) x Farm hh & $\begin{array}{l}-1.567 \\
(2.059)\end{array}$ & $\begin{array}{l}-4.360 \\
(7.528)\end{array}$ & $\begin{array}{c}3.844^{* * *} \\
(0.461)\end{array}$ & $\begin{array}{c}3.388^{* * * *} \\
(1.276)\end{array}$ & $\begin{array}{c}0.841^{* * *} \\
(0.094)\end{array}$ & $\begin{array}{c}2.487 * * * \\
(0.440)\end{array}$ & $\begin{array}{c}-0.151^{* *} \\
(0.075)\end{array}$ & $\begin{array}{l}-0.053 \\
(0.223)\end{array}$ \\
\hline Var rainfall (ln) x Farm hh x 1880 & & $\begin{array}{c}0.496 \\
(7.465)\end{array}$ & & $\begin{array}{c}0.161 \\
(1.261)\end{array}$ & & $\begin{array}{c}-1.212^{* * *} \\
(0.452)\end{array}$ & & $\begin{array}{l}-0.133 \\
(0.222)\end{array}$ \\
\hline Var rainfall (ln) x Farm hh x 1900 & & $\begin{array}{c}9.205 \\
(8.396)\end{array}$ & & $\begin{array}{c}1.327 \\
(1.404)\end{array}$ & & $\begin{array}{c}-1.687^{* * *} \\
(0.451)\end{array}$ & & $\begin{array}{l}-0.157 \\
(0.225)\end{array}$ \\
\hline Var rainfall (ln) x Farm hh x 1910 & & $\begin{array}{c}6.656 \\
(12.136)\end{array}$ & & $\begin{array}{c}1.293 \\
(1.605)\end{array}$ & & $\begin{array}{c}-1.314^{* * *} \\
(0.455)\end{array}$ & & $\begin{array}{l}-0.223 \\
(0.250)\end{array}$ \\
\hline Var rainfall (ln) x Farm hh x 1920 & & $\begin{array}{c}1.707 \\
(11.851)\end{array}$ & & $\begin{array}{l}-1.637 \\
(1.574)\end{array}$ & & $\begin{array}{c}-1.999 * * * \\
(0.463)\end{array}$ & & $\begin{array}{l}-0.042 \\
(0.229)\end{array}$ \\
\hline Var rainfall (ln) x Farm hh x 1930 & & $\begin{array}{l}-1.869 \\
(9.087)\end{array}$ & & $\begin{array}{l}-0.990 \\
(1.314)\end{array}$ & & $\begin{array}{c}-2.040^{* * *} \\
(0.441)\end{array}$ & & $\begin{array}{l}-0.107 \\
(0.235)\end{array}$ \\
\hline Full set of controls & Yes & Yes & Yes & Yes & Yes & Yes & Yes & Yes \\
\hline Rainfall (In) x Farm hh time interactions & & Yes & & Yes & & Yes & & Yes \\
\hline County fixed effects & Yes & Yes & Yes & Yes & Yes & Yes & Yes & Yes \\
\hline Time fixed effects & Yes & & Yes & & Yes & & Yes & \\
\hline State-specific time effects & & Yes & & Yes & & Yes & & Yes \\
\hline R-squared & 0.110 & 0.111 & 0.147 & 0.148 & 0.172 & 0.173 & 0.132 & 0.135 \\
\hline Observations & 67,255 & 67,255 & 422,766 & 422,766 & 901,148 & 901,148 & 69,585 & 69,585 \\
\hline Counties & 42 & 42 & 626 & 626 & 1,769 & 1,769 & 356 & 356 \\
\hline
\end{tabular}

Notes: $* * * \mathrm{p}<0.01,{ }^{* *} \mathrm{p}<0.05,{ }^{*} \mathrm{p}<0.1$. The full set of controls includes age group dummies, literacy of the women and of her spouse, whether the household is a farm household, average land value per acre, average land size per farm and average value of machinery per farm.

Source: US population census, agricultural census (IPUMS, NHGIS); PRISM Precipitation dataset; own estimations. 
Table 6. The effect of rainfall variability on fertility using decade-specific rainfall variability

\begin{tabular}{lccc}
\hline & $(1)$ & $(2)$ & $(3)$ \\
\hline Rainfall (ln) & $0.127^{* * *}$ & $0.146^{* * *}$ & $0.139^{* *}$ \\
& $(0.025)$ & $(0.026)$ & $(0.055)$ \\
Var rainfall (ln) & $0.518^{* * *}$ & $0.216^{* *}$ & 0.082 \\
& $(0.077)$ & $(0.107)$ & $(0.054)$ \\
Rainfall (ln) x Farm hh & & $0.114^{* * *}$ & -0.276 \\
& & $(0.024)$ & $(0.216)$ \\
Var rainfall (ln) x Farm hh & & $0.727^{* * *}$ & $0.666^{* * *}$ \\
& & $(0.093)$ & $(0.199)$ \\
\hline Full set of controls & Yes & Yes & Yes \\
County fixed effects & Yes & Yes & Yes \\
Time fixed effects & Yes & Yes & \\
State-specific time effects & & & Yes \\
\hline R-squared & 0.145 & 0.145 & 0.146 \\
Observations & 862,858 & 862,858 & 862,858 \\
Counties & 2,792 & 2,792 & 2,792 \\
\hline
\end{tabular}

Notes: $* * * \mathrm{p}<0.01, * * \mathrm{p}<0.05, * \mathrm{p}<0.1$. The full set of controls includes age group dummies, literacy of the women and of her spouse, whether the household is a farm household, average land value per acre, average land size per farm and average value of machinery per farm.

Source: US population census 1900-1930, agricultural census (IPUMS, NHGIS);

PRISM Precipitation dataset; own estimations. 
Table 7. The effect of rainfall variability on fertility, ruling out timing effects

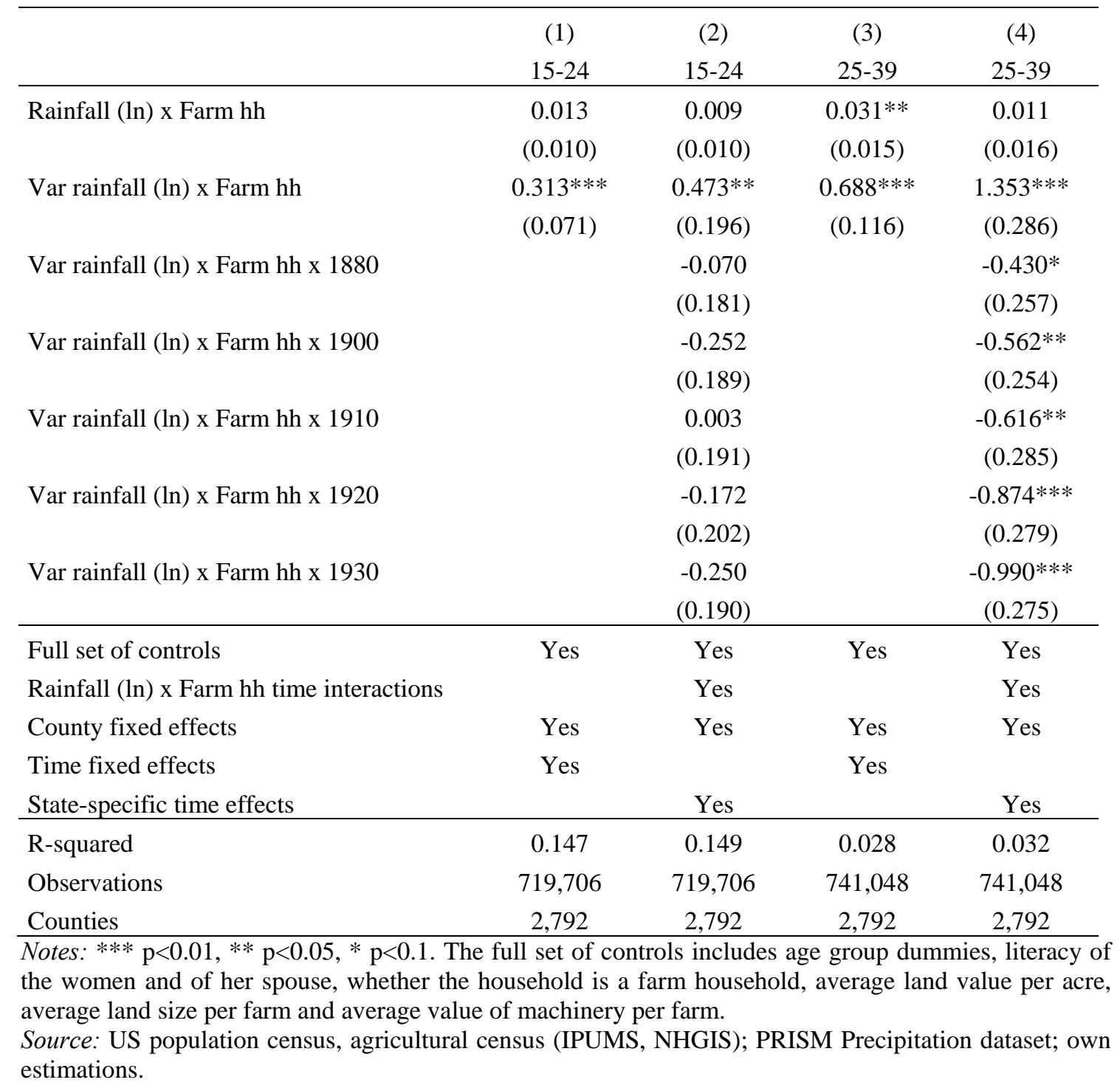


Table 8. The effect of rainfall variability on fertility, ruling out child mortality as the main channel

\begin{tabular}{|c|c|c|c|c|}
\hline & $\begin{array}{c}(1) \\
\text { Ch. born } \\
\end{array}$ & $\begin{array}{c}(2) \\
\text { Ch. born } \\
\end{array}$ & $\begin{array}{c}(3) \\
\text { Ch. born } \\
\end{array}$ & $\begin{array}{c}(4) \\
\text { Ch. mort. }\end{array}$ \\
\hline Rainfall (ln) x Farm hh & $\begin{array}{l}-0.000 \\
(0.102)\end{array}$ & & $\begin{array}{c}0.032 \\
(0.107)\end{array}$ & $\begin{array}{l}0.016^{*} \\
(0.009)\end{array}$ \\
\hline Var rainfall (ln) x Farm hh & $\begin{array}{c}1.371^{* *} \\
(0.696)\end{array}$ & & $\begin{array}{c}1.591 * * \\
(0.733)\end{array}$ & $\begin{array}{l}0.109 * \\
(0.060)\end{array}$ \\
\hline County-level child mort. & & $\begin{array}{c}-2.013^{* * *} \\
(0.255)\end{array}$ & $\begin{array}{c}-2.021^{* * *} \\
(0.255)\end{array}$ & \\
\hline Full set of controls & Yes & Yes & Yes & Yes \\
\hline County fixed effects & Yes & Yes & Yes & Yes \\
\hline R-squared & 0.412 & 0.413 & 0.413 & 0.043 \\
\hline Observations & 103,863 & 103,863 & 103,863 & 103,863 \\
\hline Counties & 2,420 & 2,420 & 2,420 & 2,420 \\
\hline
\end{tabular}


Table 9. The effect of rainfall variability on fertility, ruling out returns to education as the main channel

\begin{tabular}{lcccc}
\hline & $(1)$ & $(2)$ & $(3)$ & $(4)$ \\
& Fertility & Fertility & Fertility & Share enroll. \\
\hline Rainfall (ln) x Farm hh & $0.032^{* * *}$ & & $0.032^{* * *}$ & -0.004 \\
& $(0.011)$ & & $(0.011)$ & $(0.006)$ \\
Var rainfall (ln) x Farm hh & $0.482^{* * *}$ & & $0.468^{* * *}$ & $-0.119^{* * *}$ \\
& $(0.082)$ & & $(0.081)$ & $(0.042)$ \\
Share enrolled & & $-0.116^{* * *}$ & $-0.116^{* * *}$ & \\
& & $(0.003)$ & $(0.003)$ & \\
Full set of controls & Yes & Yes & Yes & Yes \\
County fixed effects & Yes & Yes & Yes & Yes \\
State-specific time effects & Yes & Yes & Yes & Yes \\
\hline R-squared & 0.272 & 0.274 & 0.274 & 0.141 \\
Observations & 705,897 & 705,897 & 705,897 & 705,897 \\
Counties & 2,793 & 2,793 & 2,793 & 2,793 \\
\hline
\end{tabular}

Notes: *** $\mathrm{p}<0.01,{ }^{* *} \mathrm{p}<0.05, * \mathrm{p}<0.1$. The "share enrolled" measures the women's number of children 6 to 11 years old enrolled in school over the women's number of children 6 to 11 years old whether enrolled in school or not. The full set of controls includes age group dummies, literacy of the women and of her spouse, whether the household is a farm household, average land value per acre, average land size per farm and average value of machinery per farm.

Source: US population census, agricultural census (IPUMS, NHGIS); PRISM Precipitation dataset; own estimations. 
Table 10. The effect of rainfall variability on fertility, the role of risk mitigating technologies and institutions

\begin{tabular}{|c|c|c|c|c|c|c|}
\hline & $(1)$ & $(2)$ & (3) & (4) & (5) & (6) \\
\hline Rainfall (ln) x Farm hh & $\begin{array}{c}-0.041^{* *} \\
(0.020)\end{array}$ & $\begin{array}{l}-0.039 * \\
(0.020)\end{array}$ & $\begin{array}{c}-0.028 * * \\
(0.012)\end{array}$ & $\begin{array}{l}-0.012 \\
(0.011)\end{array}$ & $\begin{array}{c}0.013 \\
(0.011)\end{array}$ & $\begin{array}{c}0.010 \\
(0.011)\end{array}$ \\
\hline Var rainfall (ln) x Farm hh & $\begin{array}{c}0.450 * * * \\
(0.133)\end{array}$ & $\begin{array}{c}0.461 * * * \\
(0.134)\end{array}$ & $\begin{array}{c}2.436^{* * *} \\
(0.235)\end{array}$ & $\begin{array}{c}1.694 * * * \\
(0.220)\end{array}$ & $\begin{array}{c}0.388 * * * \\
(0.135)\end{array}$ & $\begin{array}{c}0.375^{* * *} \\
(0.137)\end{array}$ \\
\hline Rainfall (ln) x Farm hh x Share irrig. land & $\begin{array}{c}0.025 * * \\
(0.013)\end{array}$ & $\begin{array}{c}0.024^{*} \\
(0.013)\end{array}$ & & & & \\
\hline Var rainfall (ln) x Farm hh x Share irrig. land & $\begin{array}{c}-1.035^{* * *} \\
(0.251)\end{array}$ & $\begin{array}{c}-1.042^{* * *} \\
(0.254)\end{array}$ & & & & \\
\hline Rainfall (ln) x Farm hh x Value machin. (ln) & & & $\begin{array}{c}0.001 \\
(0.001)\end{array}$ & $\begin{array}{c}0.000 \\
(0.001)\end{array}$ & & \\
\hline Var rainfall (ln) x Farm hh x Val. machin. (ln) & & & $\begin{array}{c}-0.356^{* * *} \\
(0.034)\end{array}$ & $\begin{array}{c}-0.223^{* * *} \\
(0.032)\end{array}$ & & \\
\hline Rainfall (ln) x Farm hh x Number of banks & & & & & $\begin{array}{l}-0.000 * \\
(0.000)\end{array}$ & $\begin{array}{l}-0.000 \\
(0.000)\end{array}$ \\
\hline Var rainfall (ln) x Farm hh x Number of banks & & & & & $\begin{array}{r}-0.006 \\
(0.006) \\
\end{array}$ & $\begin{array}{l}-0.005 \\
(0.006)\end{array}$ \\
\hline Full set of controls & Yes & Yes & Yes & Yes & Yes & Yes \\
\hline County fixed effects & Yes & Yes & Yes & Yes & Yes & Yes \\
\hline Time fixed effects & Yes & & Yes & & Yes & \\
\hline State-specific time effects & & Yes & & Yes & & Yes \\
\hline R-squared & 0.161 & 0.162 & 0.163 & 0.165 & 0.130 & 0.130 \\
\hline Observations & 408,247 & 408,247 & $1,460,754$ & $1,460,754$ & 453,052 & 453,052 \\
\hline Counties & 2,632 & 2,632 & 2,793 & 2,793 & 2,766 & 2,766 \\
\hline
\end{tabular}

Note: $* * * \mathrm{p}<0.01,{ }^{* *} \mathrm{p}<0.05,{ }^{*} \mathrm{p}<0.1$. Col. (1) and (2) uses data from the years 1900 and 1910. Col. (3) and (4) uses data from the years 1870 to 1930 . Col. (5) and (6) uses data from the years 1920 and 1930.

Source: US population census, agricultural census (IPUMS, NHGIS); PRISM Precipitation dataset; Survey on Bank and Bank deposits, 1920 and 1930; own estimations. 
Table A.1. The effect of rainfall and rainfall variability on agricultural production (county average value of production in constant US dollar per farm in $t$ ), county level estimates

\begin{tabular}{|c|c|c|c|c|c|c|}
\hline & (1) & (2) & (3) & (4) & (5) & (6) \\
\hline Rainfall (ln) in $t$ & $\begin{array}{c}0.395^{* * *} \\
(0.054)\end{array}$ & $\begin{array}{c}0.353^{* * *} \\
(0.053)\end{array}$ & $\begin{array}{c}0.339 * * * \\
(0.056)\end{array}$ & $\begin{array}{c}0.397^{* * *} \\
(0.054)\end{array}$ & $\begin{array}{c}0.354^{* * *} \\
(0.053)\end{array}$ & $\begin{array}{c}0.339^{* * *} \\
(0.055)\end{array}$ \\
\hline Var Rainfall (ln) in $[t-5 ; t+5]$ & & & & $\begin{array}{c}0.712 \\
(0.615)\end{array}$ & $\begin{array}{c}0.421 \\
(0.597)\end{array}$ & $\begin{array}{c}0.322 \\
(0.566)\end{array}$ \\
\hline Val. land and build. p.a. (ln) in $t$ & $\begin{array}{c}0.183^{* * *} \\
(0.053)\end{array}$ & $\begin{array}{c}0.433^{* * *} \\
(0.061)\end{array}$ & $\begin{array}{c}0.227^{* * *} \\
(0.061)\end{array}$ & $\begin{array}{c}0.184^{* * *} \\
(0.053)\end{array}$ & $\begin{array}{c}0.433^{* * *} \\
(0.061)\end{array}$ & $\begin{array}{c}0.227^{* * *} \\
(0.061)\end{array}$ \\
\hline Av. farm size $(\ln )$ in $t$ & & $\begin{array}{c}0.471^{* * *} \\
(0.037)\end{array}$ & $\begin{array}{c}0.209^{* * *} \\
(0.044)\end{array}$ & & $\begin{array}{c}0.470^{* * *} \\
(0.037)\end{array}$ & $\begin{array}{c}0.208^{* * *} \\
(0.044)\end{array}$ \\
\hline Av. value machinery (ln) in $t$ & & & $\begin{array}{c}0.467 * * * \\
(0.057)\end{array}$ & & & $\begin{array}{c}0.466^{* * *} \\
(0.057)\end{array}$ \\
\hline County fixed effects & Yes & Yes & Yes & Yes & Yes & Yes \\
\hline State-specific time effects & Yes & Yes & Yes & Yes & Yes & Yes \\
\hline R-squared & 0.736 & 0.755 & 0.771 & 0.737 & 0.755 & 0.771 \\
\hline Observations & 10,707 & 10,707 & 10,707 & 10,707 & 10,707 & 10,707 \\
\hline Counties & 2,797 & 2,797 & 2,797 & 2,797 & 2,797 & 2,797 \\
\hline
\end{tabular}

Note: $* * * \mathrm{p}<0.01, * * \mathrm{p}<0.05,{ }^{*} \mathrm{p}<0.1$.

Source: US population census 1900-1930, agricultural census (IPUMS, NHGIS); PRISM Precipitation dataset; own estimations. 


\section{Figures}

Figure 1. Children under five per women aged 15 to 39 (cross-section), rural areas only

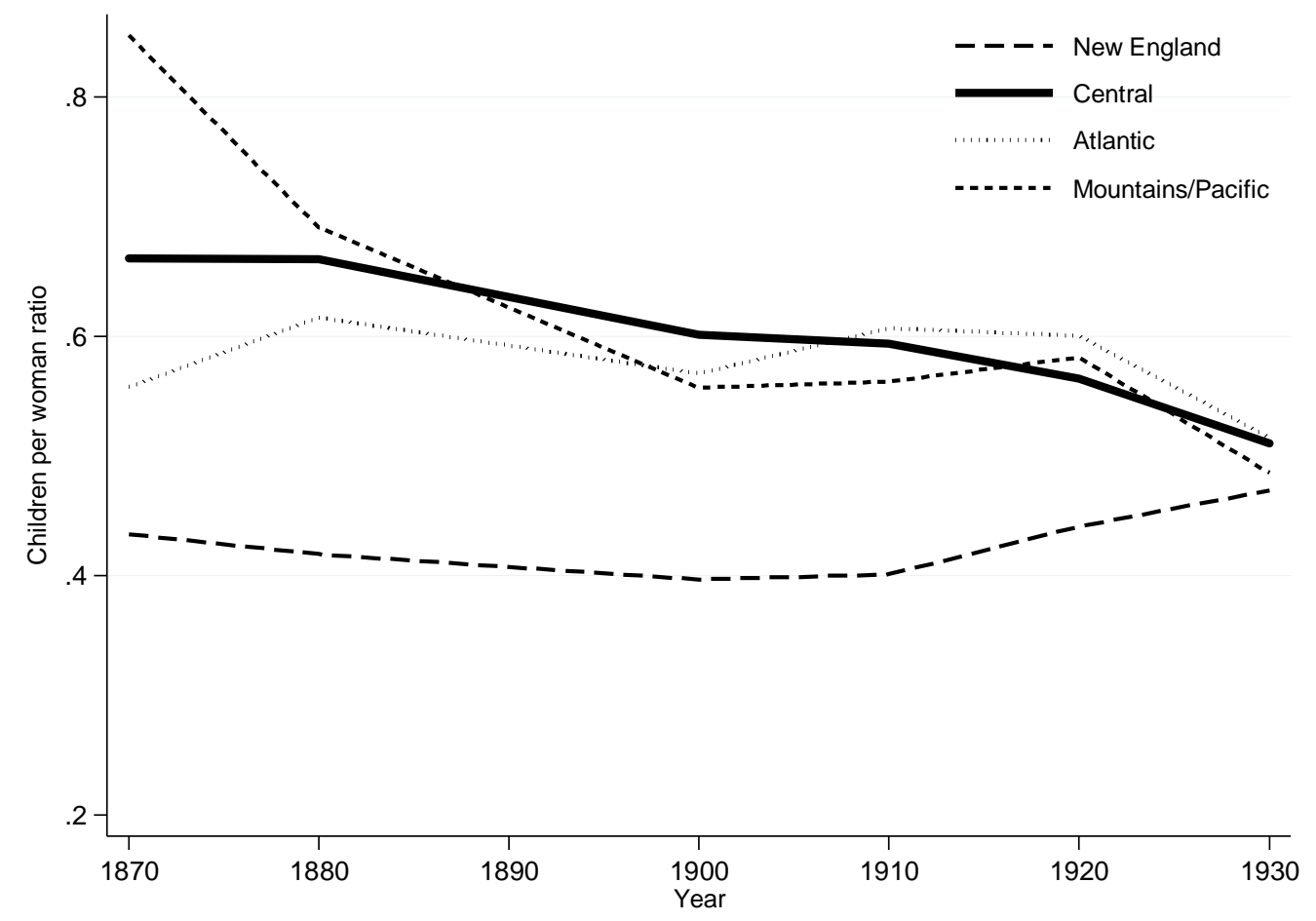

Source: US population census (IPUMS); own estimations. 
Figure 2: Fertility over time and counties (rural areas)
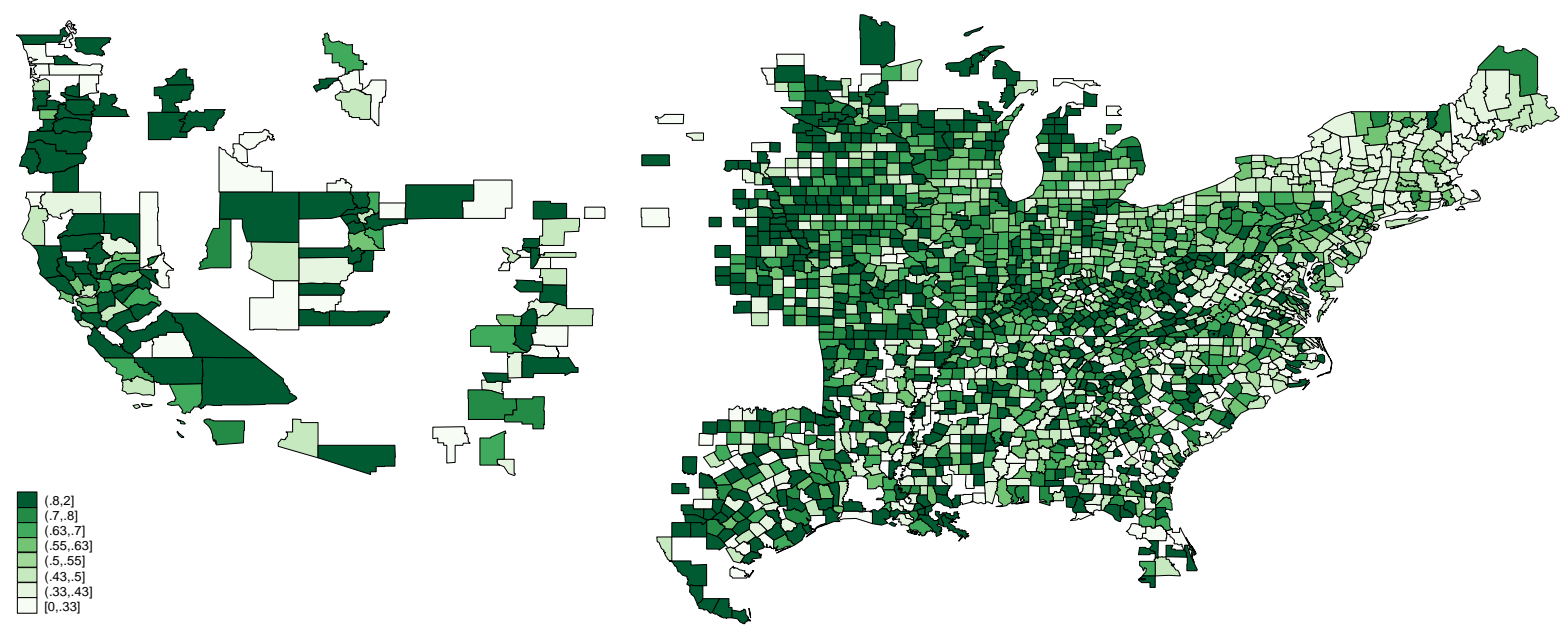

1870

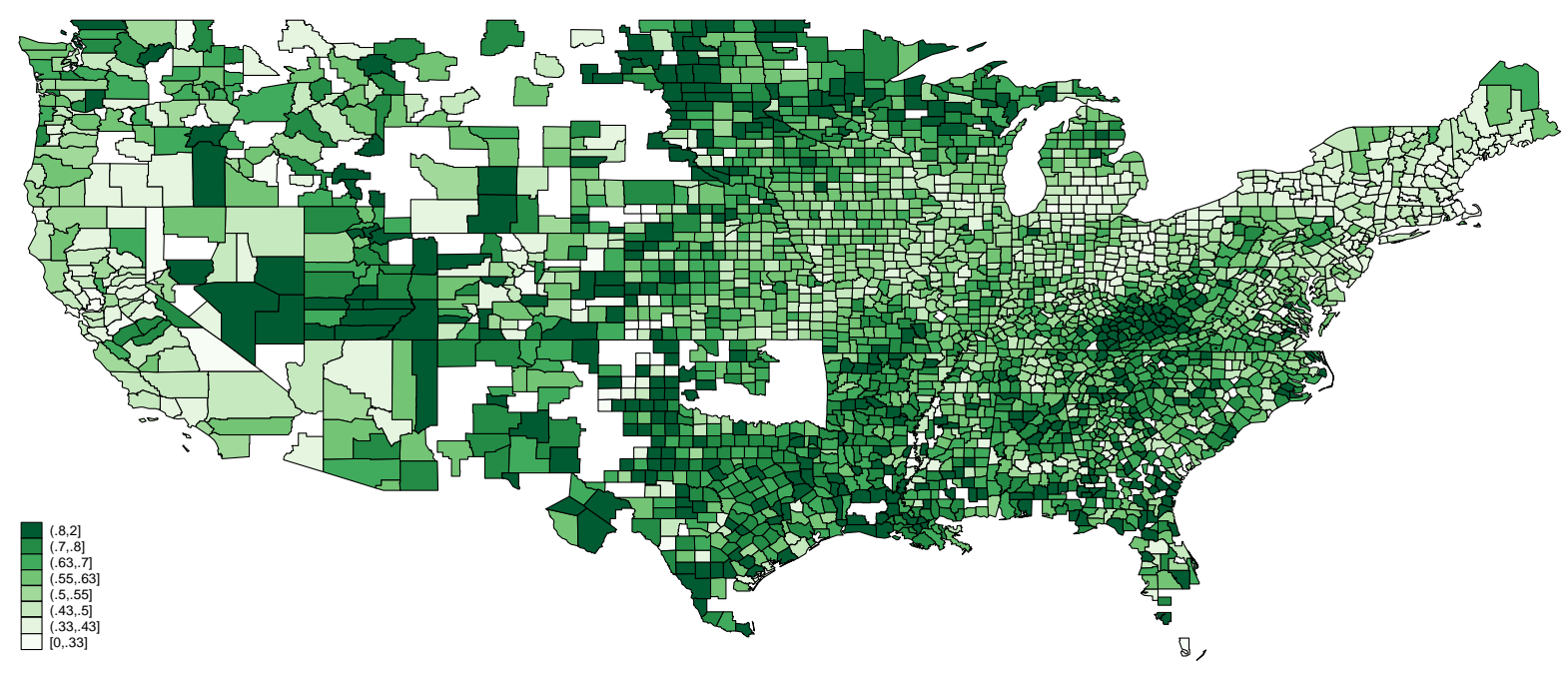

1900 

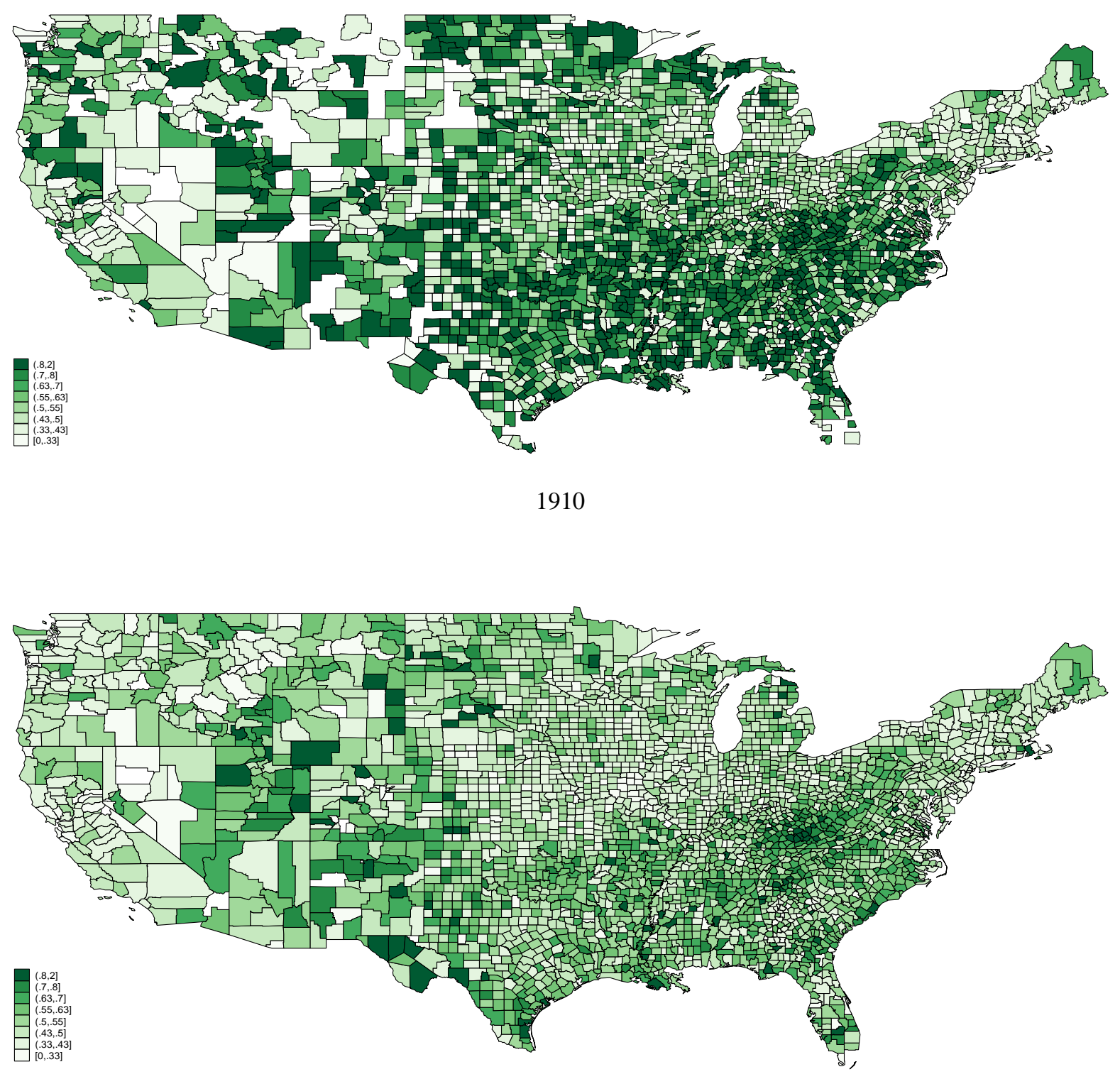

1930

Source: US population census (IPUMS); own estimations. 
Figure 3. Rainfall levels and rainfall risk

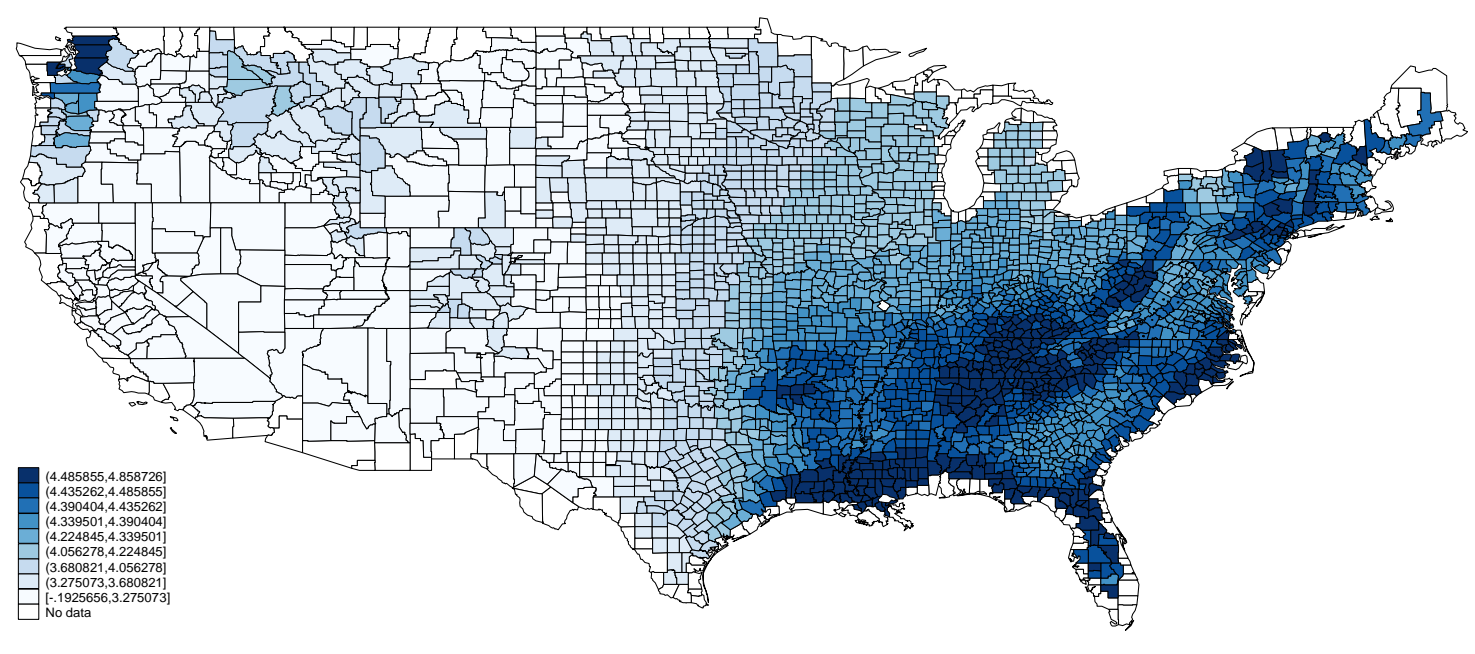

Rainfall level

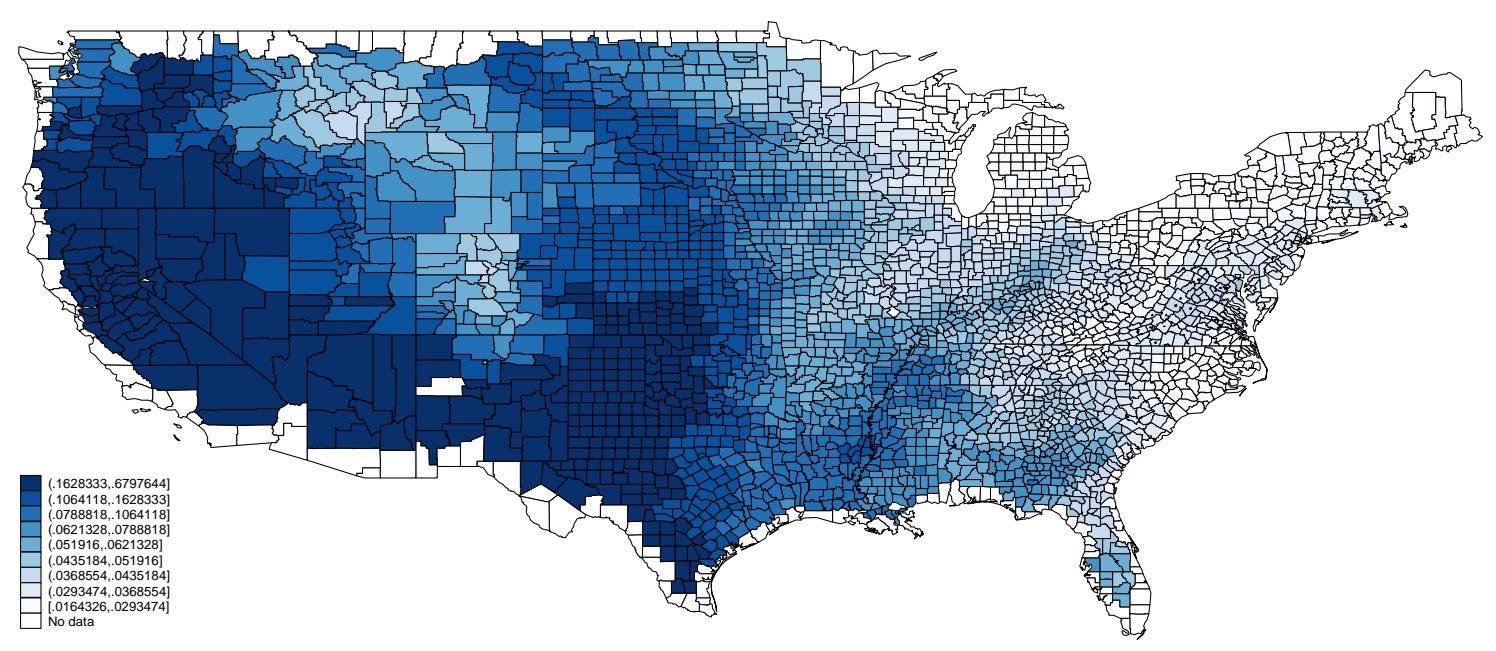

Rainfall variance

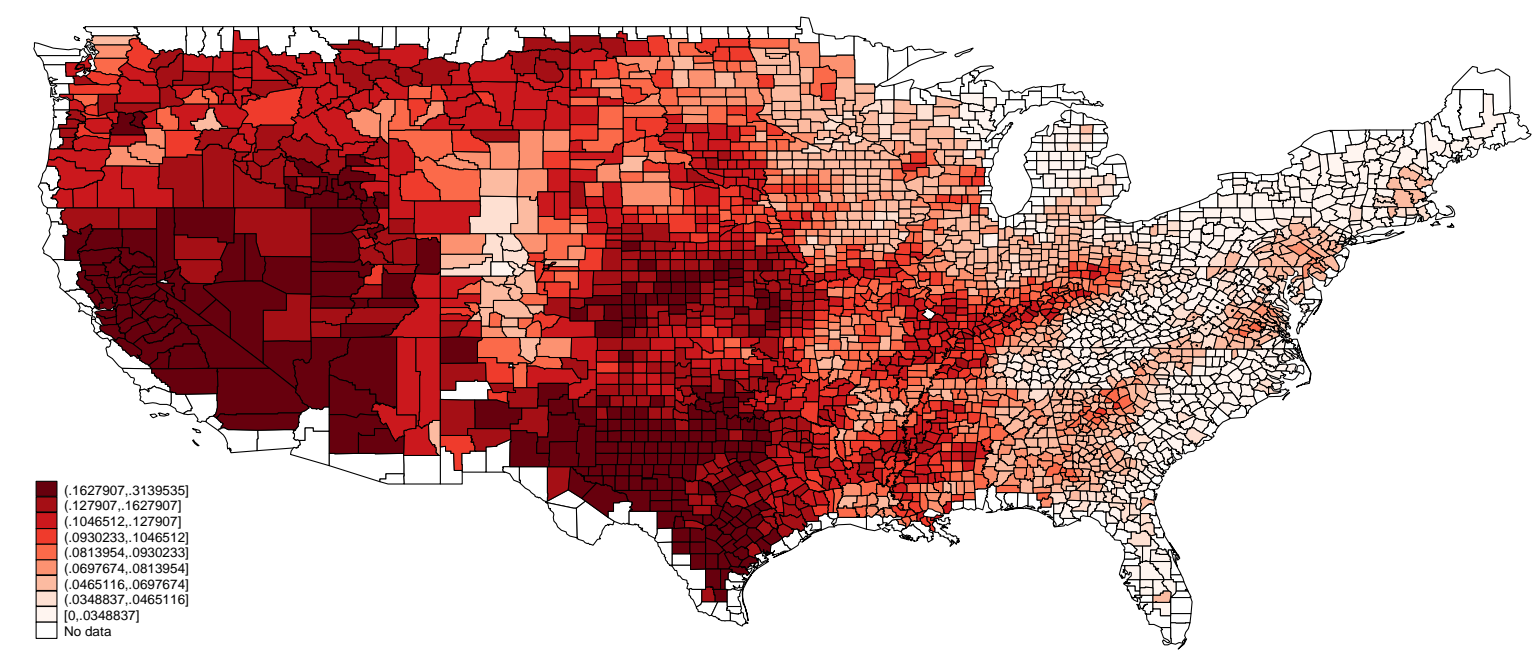

Risk of drought

Source: PRISM data set; own estimations. 
Figure 4: The effect of rainfall variability on fertility over time

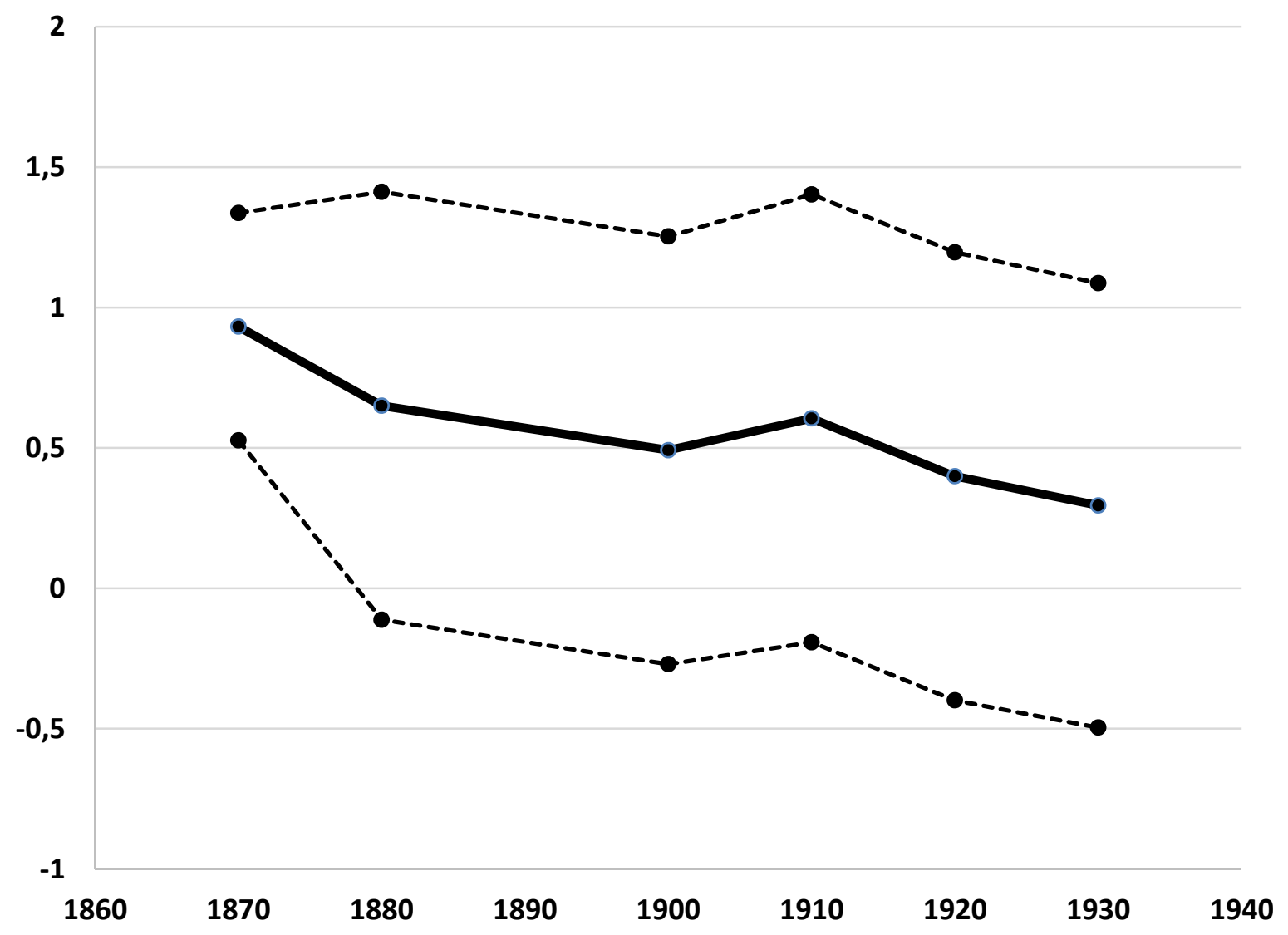

Notes: The left axis shows the regression coefficients along with the corresponding confidence intervals drawn from Tale 4, col. (5).

Source: US population census, agricultural census (IPUMS, NHGIS); PRISM Precipitation dataset; own estimations. 
Figure 5. Use of irrigation systems

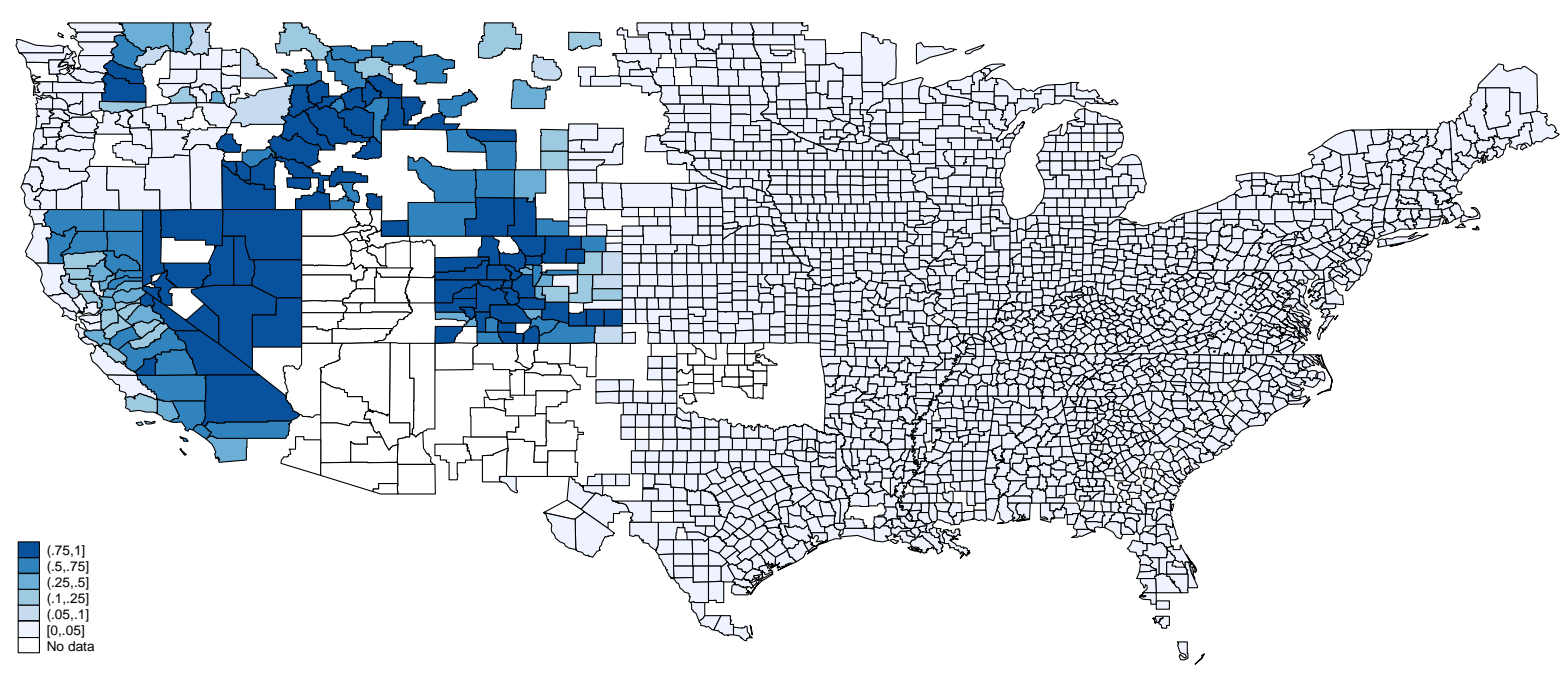

1900

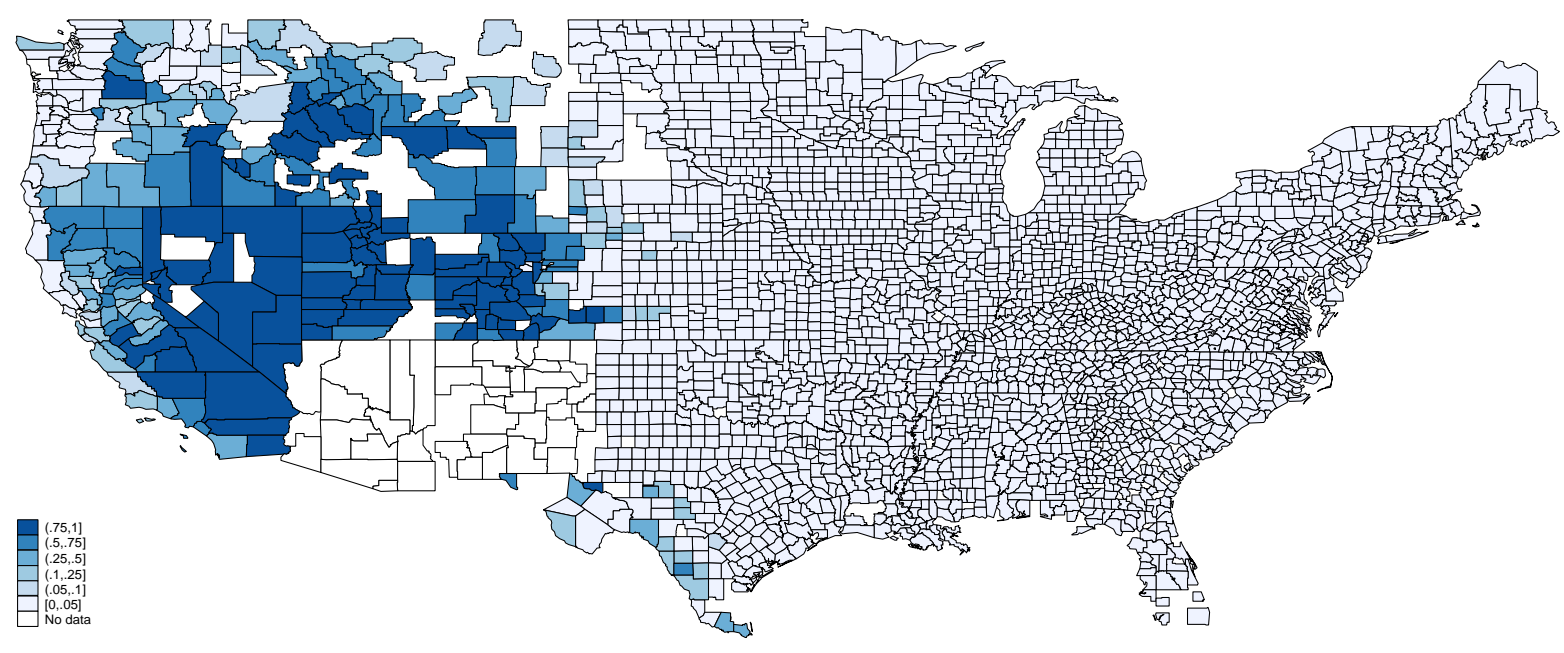

1910

Source: US agricultural census (NHGIS). 
Figure 6. Use of agricultural machinery
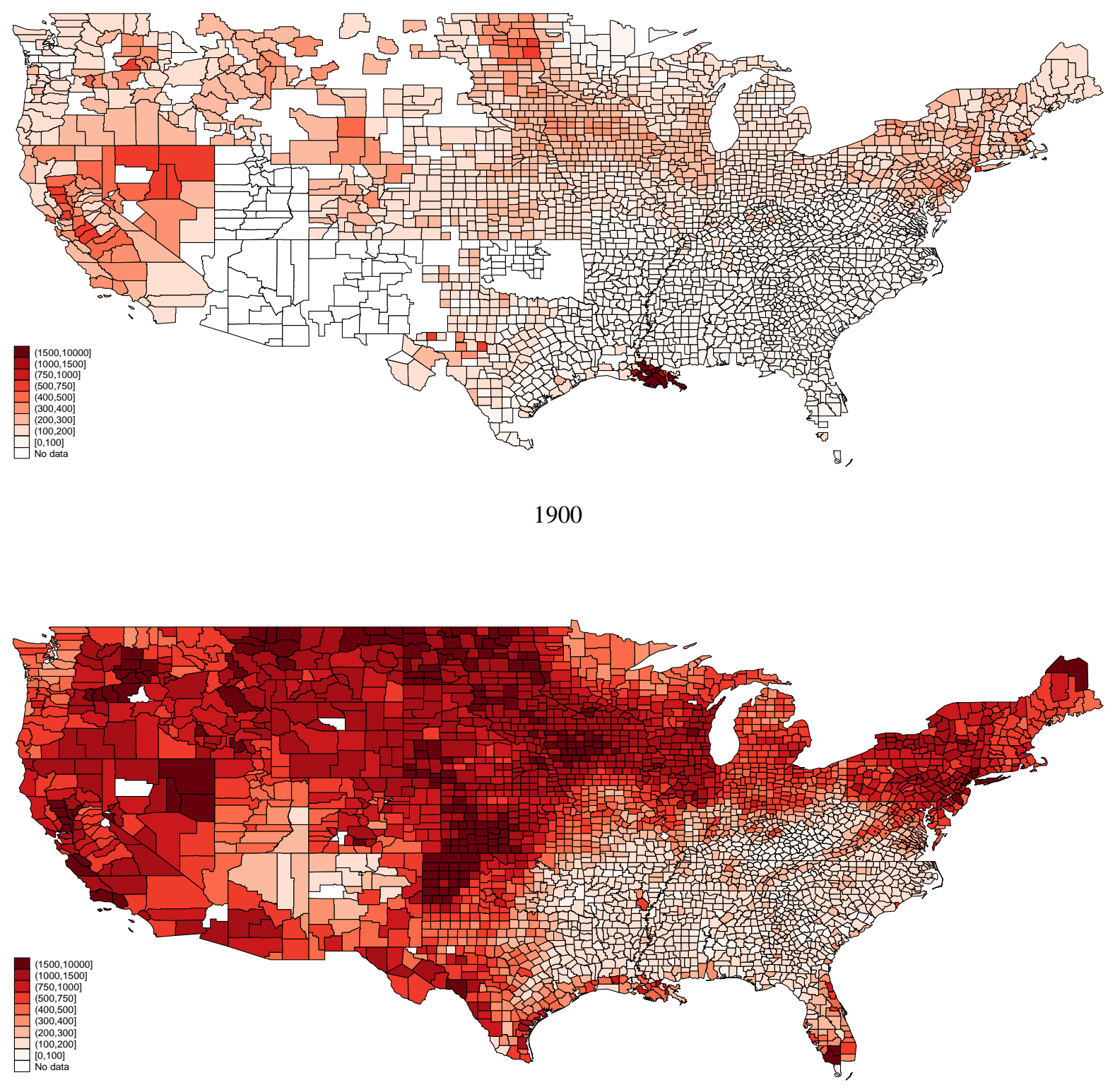

1930

Source: US agricultural census (NHGIS). 
Figure 7. Spread of banks

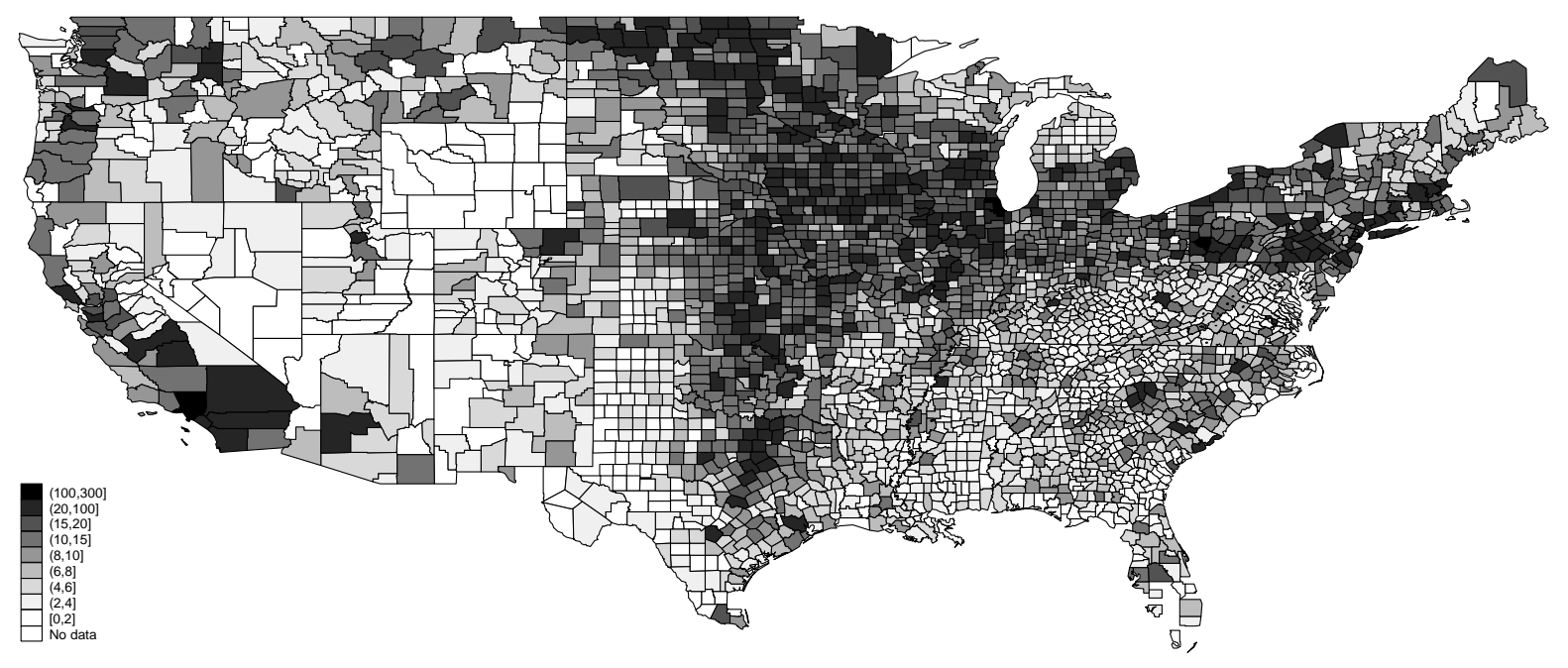

1920

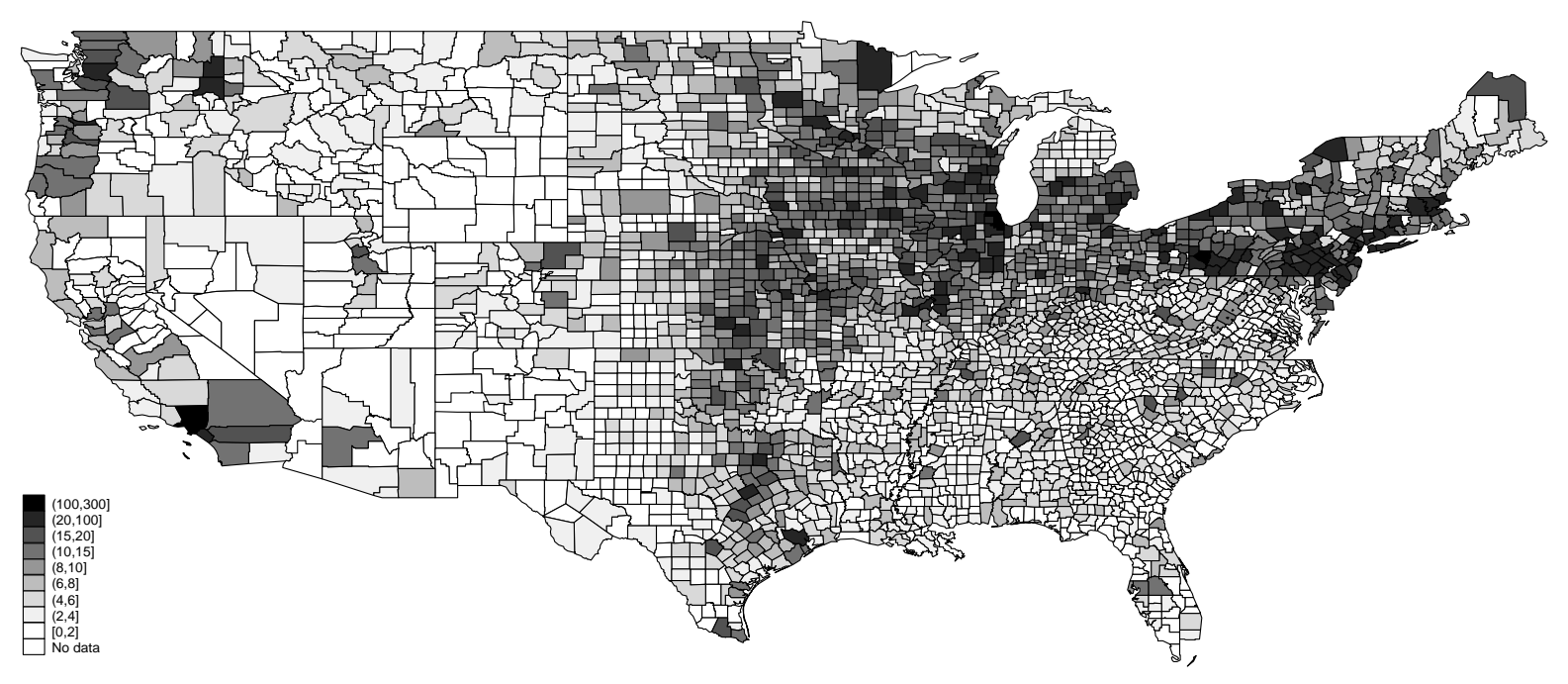

1930

Source: Survey on Bank and Bank deposits, 1920 and 1930. 
Figure A.1. Definition of regions

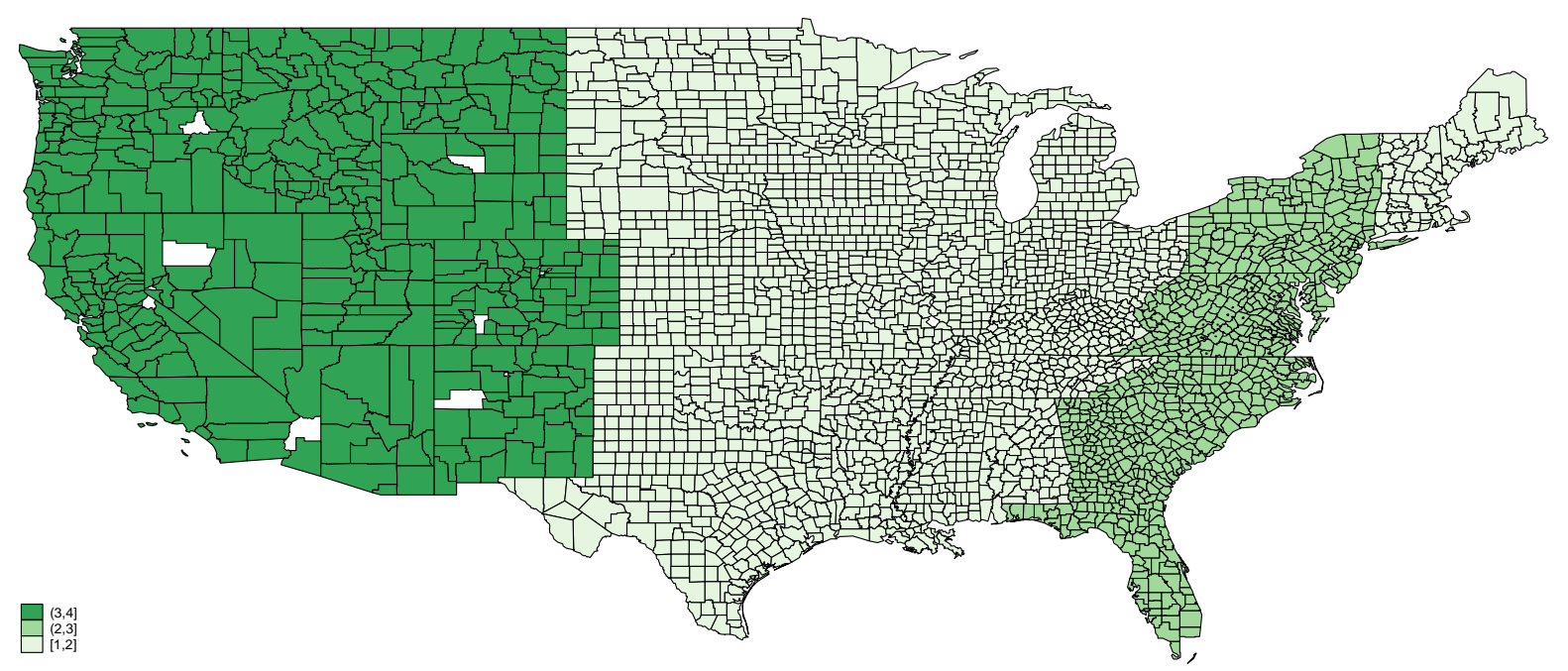

Note: From left to right: Mountains/Pacific, Central, Atlantic and New England.

Source: US population census (IPUMS); own computations. 


\section{Rainfall risk and fertility: Evidence from farm settlements during the American demographic transition}

\section{Online appendix - Not intended for print publication}

Figure S.1: The evolution of the ratio between children aged under five and children ever born over time

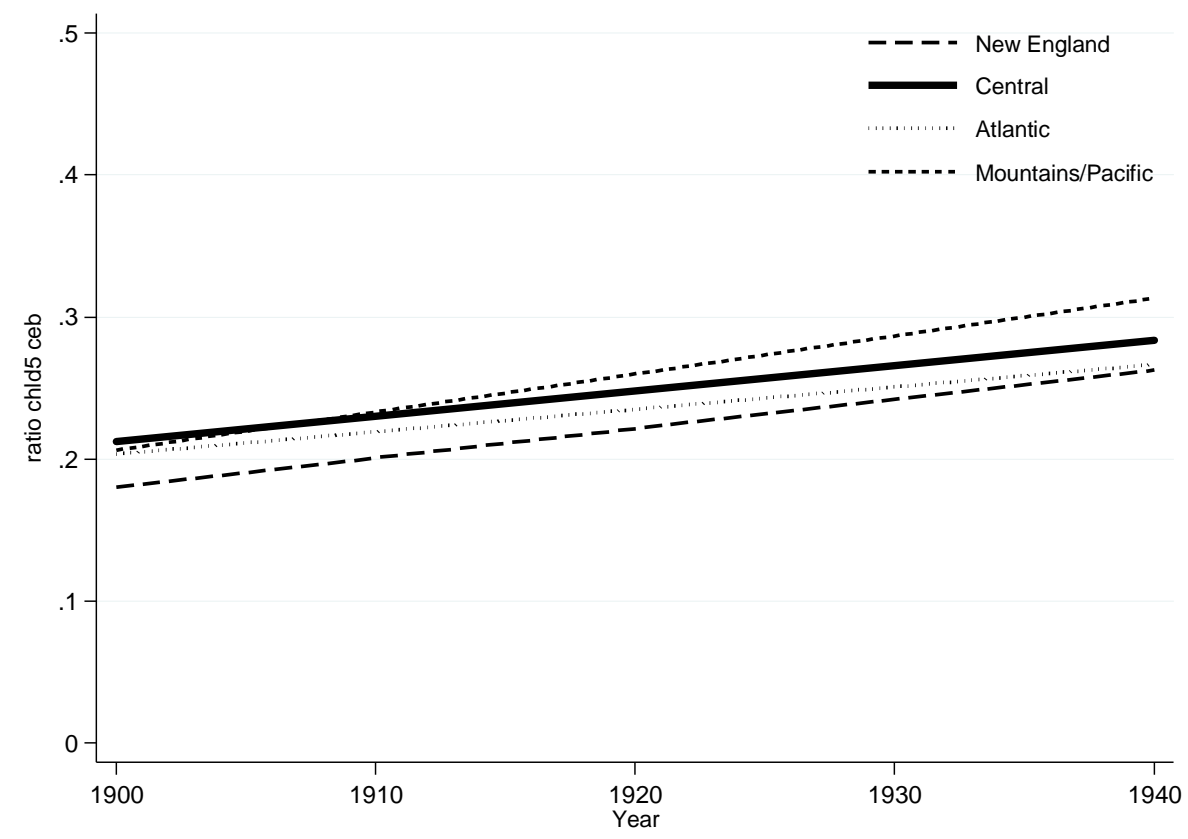

Source: US population census, 1900 and 1940 (IPUMS); own estimations. 